\title{
Selenomethionine Mitigates Cognitive Decline by Targeting Both Tau Hyperphosphorylation and Autophagic Clearance in an Alzheimer's Disease Mouse Model
}

\author{
Zhong-Hao Zhang, ${ }^{1}$ Qiu-Yan Wu, ${ }^{1}$ Rui Zheng, ${ }_{1}$ Chen Chen, ${ }^{1}$ Yao Chen, ${ }^{1}{ }^{\circledR}$ Qiong Liu, ${ }^{1}$ Peter R. Hoffmann, ${ }^{2}$ Jia-Zuan Ni, ${ }^{1}$

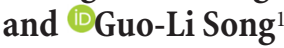 \\ ${ }^{1}$ Shenzhen Key Laboratory of Marine Bioresources and Ecology, College of Life Sciences and Oceanography, Shenzhen University, Shenzhen, 518060, China, \\ and ${ }^{2}$ Department of Cell and Molecular Biology, John A. Burns School of Medicine, University of Hawaii, Honolulu, Hawaii 96813
}

Tau pathology was recently identified as a key driver of disease progression and an attractive therapeutic target in Alzheimer's disease (AD). Selenomethionine (Se-Met), a major bioactive form of selenium (Se) in organisms with significant antioxidant capacity, reduced the levels of total tau and hyperphosphorylated tau and ameliorated cognitive deficits in younger triple transgenic $\mathrm{AD}(3 \mathrm{xTg}-\mathrm{AD})$ mice. Whether Se-Met has a similar effect on tau pathology and the specific mechanism of action in older 3xTg-AD mice remains unknown. Autophagy is a major self-degradative process to maintain cellular homeostasis and function. Autophagic dysfunction has been implicated in the pathogenesis of multiple age-dependent diseases, including AD. Modulation of autophagy has been shown to retard the accumulation of misfolded and aggregated proteins and to delay the progression of AD. Here, we found that 3xTg-AD mice showed significant improvement in cognitive ability after a 3-month treatment with Se-Met beginning at 8 months of age. In addition to attenuating the hyperphosphorylation of tau by modulating the activity of Akt/glycogen synthase kinase- $3 \beta$ and protein phosphatase $2 \mathrm{~A}$, Se-Met-induced reduction of tau was also mediated by an autophagy-based pathway. Specifically, Se-Met improved the initiation of autophagy via the AMP-activated protein kinase-mTOR (mammalian target of rapamycin) signaling pathway and enhanced autophagic flux to promote the clearance of tau in 3xTg-AD mice and primary 3xTg neurons. Thus, our results demonstrate for the first time that Se-Met mitigates cognitive decline by targeting both the hyperphosphorylation of tau and the autophagic clearance of tau in AD mice. These data strongly support Se-Met as a potent nutraceutical for AD therapy.

Key words: Alzheimer's disease; autophagy; hyperphosphorylated tau; selenomethionine; tau; tauopathy

Significance Statement

Selenium has been widely recognized as a vital trace element abundant in the brain with effects of antioxidant, anticancer, and anti-inflammation. In this study, we report that selenomethionine rescues spatial learning and memory impairments in aged $3 \mathrm{xTg}-\mathrm{AD}$ mice via decreasing the level of tau protein and tau hyperphosphorylation. We find that selenomethionine promotes the initiation of autophagy via the AMPK-mTOR pathway and enhances autophagic flux, thereby facilitating tau clearance in vivo and in vitro. We have now identified an additional, novel mechanism by which selenomethionine improves the cognitive function of AD mice. Specifically, our data suggest the effect of selenium/selenomethionine on an autophagic pathway in Alzheimer's disease.

\section{Introduction}

Alzheimer's disease (AD), the most common type of dementia in aged people, is an untreatable neurodegenerative disorder char- acterized by abnormal accumulations of $\beta$-Amyloid $(\mathrm{A} \beta)$ oligomers and intracellular neurofibrillary tangles (NFTs) in the brain attributable to hyperphosphorylated tau that results in pro- 
gressive synaptic dysfunction and cognitive deficits (Balducci and Forloni, 2014; Orr et al., 2014; Shibuya et al., 2014; Alzheimer's Association, 2015; Sui et al., 2015). A $\beta$ has been widely viewed as the principal therapeutic target of AD. However, increasing evidence suggests that the generation of $\mathrm{A} \beta$ and tau dysfunction have an intrinsic relationship and together may synergistically trigger disease pathogenesis (Eckert et al., 2010; Hurtado et al., 2010; Yu et al., 2014). Pathological alterations in tau mediate A $\beta$ and inflammation-induced neurotoxicity, and a reduction in tau can prevent $\mathrm{A} \beta$ - and inflammation-induced neurodegeneration (Vossel et al., 2010, 2015; Maphis et al., 2015). Tau pathology (tauopathy) better correlates with cognitive impairment in $\mathrm{AD}$ patients than $\mathrm{A} \beta$ pathology. Thus, tau has emerged as a meaningful target for pathological research and pharmaceutical interventions for $\mathrm{AD}$.

Tau is a microtubule-associated protein encoded by the MAPT gene located on chromosome 17 that dynamically regulates the polymerization, stability, and assembly of axonal microtubules (Gendron and Petrucelli, 2009). An increasing body of evidence suggests that tauopathies caused by pathological changes in tau proteins (e.g., misfolding, mislocalization, and hyperphosphorylation) exist in $>30$ neurodegenerative diseases, with hyperphosphorylated tau presenting as a pathological feature of AD (Berger et al., 2007; Kopeikina et al., 2012). Tau hyperphosphorylation is site specific and mainly occurs at serine/threonine residues, such as Thr231, Thr235, Ser396, Ser404, Ser262, and Ser202 (Ding et al., 2006; Wang et al., 2014). Thus, serine/threonine protein kinases and phosphatases that regulate tau phosphorylation directly, such as glycogen synthase kinase-3 $\beta$ (GSK3 $\beta$ ) and protein phosphatase $2 A$ (PP2A), may play a crucial role in AD-related tau pathology (Hu et al., 2006). Inhibition of GSK3 $\beta$ or activation of PP2A ameliorated cognitive impairment in $\mathrm{AD}$ mice by attenuating tau hyperphosphorylation (Y. Zhang et al., 2014; Castro-Alvarez et al., 2015). We previously reported that selenomethionine (Se-Met), a major form of dietary selenium (Se) with powerful antioxidant capacity, reduced tau hyperphosphorylation by modulating the activity of GSK $3 \beta$ and PP2A in 4-month-old triple transgenic $\mathrm{AD}$ mice $(3 \mathrm{xTg}-\mathrm{AD}$; Song et al., 2014). Our study was the first to reveal that Se-Met has a positive effect on cognitive ability and tau pathology in $\mathrm{AD}$. However, potential mechanisms by which this occurs remain unclear. In 3xTg-AD mice, human mutant P301L-tau is an abnormally overexpressed protein that is particularly prone to misfolding and site-specific hyperphosphorylation (Santacruz et al., 2005; Terwel et al., 2005; Hunsberger et al., 2014). Therefore, besides reducing hyperphosphorylation, clearance of this mutant tau protein or abnormally hyperphosphorylated tau could represent another method to prevent tauopathies.

Macroautophagy is a major cellular pathway for the degradation and clearance of damaged organelles and/or denatured and aggregated proteins/peptides. The autophagy process serves to maintain cellular homeostasis, which depends on the fusion of autophagosomes and lysosomes (i.e., autophagolysosomal fusion; Levine and Klionsky, 2004; Mizushima et al., 2008). Previous studies have shown that autophagic dysfunction in the CNS causes neurodegeneration in mice and that defects in autophagosome formation and autophagosome-lysosome fusion occur early during $\mathrm{AD}$ pathogenesis (Komatsu et al., 2006; Zare-Shahabadi et al., 2015). Promoting autophagy initiation, autolysosome formation, and lysosome biogenesis reduced the expression and aggregation of abnormal tau protein in AD models (Shibuya et al., 2014; Y. Kim et al., 2015; Siman et al., 2015). Oxidative stress can regulate autophagic pathways in neurodegeneration, and autophagy may functionally bridge oxidative stress and the development of AD (Zheng et al., 2006; Hensley and Harris-White, 2015). Based on our research and other previous studies, integrated pathological characteristics of tau occur at $\sim 8-12$ months of age in the 3xTg-AD mouse (Oddo et al., 2003a,b). Thus, in this study, the therapeutic effect and underlying mechanisms of Se-Met on tau pathology were explored in 8-month-old AD mice. We found that Se-Met rescued cognitive impairments of 3xTg-AD mice, modulated the activity of Akt/GSK3 $\beta$ and PP2A to decrease hyperphosphorylated tau, initiated autophagy via the AMP-activated protein kinase (AMPK)-mammalian target of rapamycin (mTOR) pathway, and enhanced autophagic flux to promote the autophagic clearance of tau in aged 3xTg-AD mice.

\section{Materials and Methods}

Animals and treatment. 3xTg-AD and wild-type (WT) mice were purchased from The Jackson Laboratory (hybrid 129/C57BL6 background, JAX order number 3591206). These mice express the mutant human APPswe and tauP301L genes and the mutant mouse PS1M146V gene. $3 \mathrm{xTg}-\mathrm{AD}$ mice (the fourth generation) at 8 months of age ( $n=12$; six males and six females) were treated with $6 \mu \mathrm{g} / \mathrm{ml} \mathrm{Se-Met} \mathrm{(Sigma-}$ Aldrich) in their drinking water for 12 weeks. The control mice and WT mice ( $n=12$ per group; six males and six females in each group) received normal drinking water. The body weight of each mouse was recorded every 2 weeks. The mice were maintained under standard laboratory conditions, including a $12 \mathrm{~h}$ light/dark cycle, a temperature of $22 \pm 2^{\circ} \mathrm{C}$, and ad libitum access to water and food. Each cage housed three to four mice with the same genotype.

After treatment with Se-Met for 12 weeks and the subsequent behavioral testing, mice were killed and their brains were rapidly removed. The left hemisphere was immersion fixed with $4 \%$ paraformaldehyde for $24 \mathrm{~h}$, dehydrated with a graded ethanol series, cleared with xylene, infiltrated with wax, and cut into 5 - $\mu \mathrm{m}$-thick sections. The right hemisphere was dissected into hippocampal and cortical samples, snap frozen in liquid nitrogen, and stored at $-80^{\circ} \mathrm{C}$ until analysis. The experiments and procedures were performed in strict accordance with the institutional guidelines regarding experimental animal use at Shenzhen University. The protocol was approved by the Animal Ethical and Welfare Committee of Shenzhen University (permit number AEWC-20140615-002). All efforts were made to minimize suffering.

Morris water maze. WT mice (11 months old), 3xTg-AD mice, and Se-Met-treated mice were trained in a round, water-filled tub $(160 \mathrm{~cm}$ in diameter and $50 \mathrm{~cm}$ in height) as described previously (Song et al., 2014). Each mouse was given four trials per day for 5 consecutive days with a $15 \mathrm{~min}$ intertrial interval. The first day was designated as the training day, and the maximum trial length was $60 \mathrm{~s}$. If mice did not reach the platform in the allotted time, they were manually guided to it, where they remained for $15 \mathrm{~s}$. After the $5 \mathrm{~d}$ of task acquisition, probe trials were performed 24 and $72 \mathrm{~h}$ later to assess short-term and long-term memory consolidation. The platform was removed, and the mice were placed into the quadrant of the pool opposite to the original platform quadrant. In each probe trial, mice were allowed to swim for $60 \mathrm{~s}$. The time mice spent in the original platform quadrant and the number of times the mice crossed the platform position were recorded. All trials were recorded using an HVS water maze program for subsequent analyses of escape latency and swimming speed (WaterMaze 3; Actimetrics).

Step-down test. The mice were subjected to a step-down test in a passive avoidance chamber. The floor of the chamber consisted of copper rods and a well-insulated platform made of rubber in a corner of the chamber. Mice were placed in the chamber for a $3 \mathrm{~min}$ adaptation period and then placed on the platform. The latency to step down on the grid with all four paws was measured. After stepping down on the copper bars, the mice received an immediate mild electrical shock $(36 \mathrm{~V})$. To avoid the shock, mice showed an instinctive reaction to jump back onto the platform. Mice were tested in this manner for $5 \mathrm{~min}$. The number of times mice stepped down from the platform within 5 min was defined as the acquisition error. After $24 \mathrm{~h}$, this procedure was repeated, and the stepdown latency (SDL) was used as a measurement of memory retention. The number of times that mice stepped down onto the platform within the 3 min interval was recorded as the error time. 
Table 1. Antibody information

\begin{tabular}{llll}
\hline Antibody & Host & Application & Source \\
\hline Tau5 & Mouse & IMB/IMF & Abcam \\
Tau-pS404 & Rabbit & IMB/IMF & Abcam \\
Akt & Rabbit & IMB & Cell Signaling \\
p-Akt & Rabbit & IMB & Cell Signaling \\
GSK3 $\beta$ & Mouse & IMB & Cell Signaling \\
p-GSK3 $\beta$ & Rabbit & IMB & Cell Signaling \\
PP2A & Rabbit & IMB & Cell Signaling \\
p-PP2A & Rabbit & IMB & Epitomics \\
Map2 & Chicken & IMF & Abcam \\
mTOR & Rabbit & IMB & Cell Signaling \\
p-mTOR & Rabbit & IMB & Cell Signaling \\
P70S6K & Rabbit & IMB & Cell Signaling \\
p-P70S6K & Rabbit & IMB & Cell Signaling \\
AMPK $\alpha$ & Rabbit & IMB & Cell Signaling \\
p-AMPK $\alpha$ & Rabbit & IMB & Cell Signaling \\
SOSTM1/p62 & Rabbit & IMB & Santa Cruz Biotechnology \\
Cathepsin D & Rabbit & IMB/IMF & Cell Signaling \\
LC3 & Rabbit & IMB/IMF & Sigma \\
LC3B & Rabbit & IMB/IMF & Genetex \\
GAPDH & Mouse & IMB & Proteintech \\
$\beta-A c t i n$ & Mouse & IMB & Proteintech \\
\hline IMBIImun & & &
\end{tabular}

IMB, Immunoblot; IMF, immunofluorescence.

Western blot analysis. The right hemibrain was dissected into hippocampal and cortical samples and homogenized in 9 vol of Trisbuffered saline (TBS) with a protease inhibitor mixture and phosphatase inhibitors (Roche). The samples were centrifuged at $13,000 \times g$ for $1.5 \mathrm{~h}$ at $4^{\circ} \mathrm{C}$. The TBS-soluble supernatants were collected, and the pellets were resuspended in 2 vol of 5\% SDS containing a protease inhibitor mixture and phosphatase inhibitors. The TBS-insoluble pellet mixtures were sonicated for $1 \mathrm{~min}$ in an ice bath and centrifuged at 13,000 $\times \mathrm{g}$ for $30 \mathrm{~min}$ at $4^{\circ} \mathrm{C}$. The supernatants of TBS-insoluble homogenates were also collected. The protein concentration of each sample was determined using the bicinchoninic acid assay (Sigma-Aldrich). Proteins $(20 \mu \mathrm{g})$ were loaded into each lane of a 10-15\% SDS-polyacrylamide gel. After electrophoresis, proteins were transferred onto $0.45 \mathrm{~nm}$ polyvinylidene difluoride membranes (Millipore) at $100 \mathrm{~mA}$ for $1.5 \mathrm{~h}$. The membrane was then blocked with $5 \%$ fat-free milk in TBS for $2 \mathrm{~h}$ at $37^{\circ} \mathrm{C}$, followed by incubation with primary antibodies (Table 1 ) overnight at $4^{\circ} \mathrm{C}$ and horseradish peroxidase-conjugated secondary antibodies (anti-mouse and anti-rabbit; NeoBioscience) for $1 \mathrm{~h}$ at $37^{\circ} \mathrm{C}$. The immunoreactive bands were visualized with an electroluminescence kit and scanned for densitometric analysis using an imaging system (Image Station $4000 \mathrm{M}$; Kodak) and Quantity One software (Bio-Rad). $\beta$-Actin and GAPDH were used as the loading control.

Immunofluorescent staining. Sagittal paraffin sections (5 $\mu \mathrm{m}$ thick) of mouse brains were mounted on glass slides. The sections were pretreated with $0.01 \mathrm{~mol} / \mathrm{L}$ citrate buffer, $\mathrm{pH}$ 6.0, in hyperthermy for $5 \mathrm{~min}$ and blocked with 5\% goat serum in PBS for $10 \mathrm{~min}$. Next, the sections were incubated with primary antibodies overnight at $4^{\circ} \mathrm{C}$, followed by incubation with secondary antibodies (1:500 in PBS) for $1 \mathrm{~h}$ at $37^{\circ} \mathrm{C}$. The primary antibodies used in this study were summarized in Table 1 . The primary antibodies were detected using Alexa Fluor fluorescent dyeconjugated secondary antibodies (anti-mouse and anti-rabbit; Alexa Fluor 488 and 695, Multi Sciences Biotech). Three equidistant sections that included the whole hippocampal and frontal cortical areas were evaluated per animal. For the analysis and quantification of immunoreactive areas, the sections were imaged by fluorescence microscopy (Olympus).

Primary neuron cultures. Primary cortical neurons were obtained from postnatal (P0-P1) pups of WT and 3xTg-AD mice. Briefly, cortices were dissected from the brains and digested with $2 \mathrm{mg} / \mathrm{ml}$ papain for $30 \mathrm{~min}$ at $37^{\circ} \mathrm{C}$. Digested tissue was triturated by pipetting in DMEM with $10 \%$ FBS. Dissociated cells were cultured in neurobasal medium supplemented with 2\% B27, $0.5 \mathrm{~mm}$ L-glutamine, and $50 \mathrm{U} / \mathrm{ml}$ penicillin-streptomycin using poly-D-lysine-coated six-well cell culture plates at a density of $0.5 \times 10^{6}$ cells/well. For confocal microscopy, cells were seeded onto $13 \mathrm{~mm}$ glass coverslips precoated with poly-D-lysine and incubated in 24-well cell culture plates at a density of $1.5 \times 10^{5}$ cells/well. The medium was completely replaced after $4 \mathrm{~h}$, and half of the medium was subsequently replaced every 3 d. To observe the effects of Se-Met on tau pathology, the neurons were treated on day 8 with $1 \mu \mathrm{M}$ Se-Met for $24 \mathrm{~h}$.

Cell culture, transfection, and bafilomycin A1 treatment. Mouse neuroblastoma Neuro-2a (N2a) cells stably expressing human APP695 (N2a-sw cells) were obtained from Prof. Yunwu Zhang (Institute for Biomedical Research, Xiamen University, Xiamen, China). Cells were

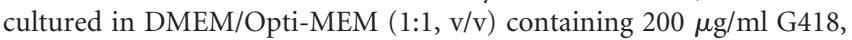
$10 \%$ fetal bovine serum, $100 \mathrm{U} / \mathrm{ml}$ penicillin, and $100 \mathrm{mg} / \mathrm{ml}$ streptomycin at $37^{\circ} \mathrm{C}$ in humidified $5 \% \mathrm{CO}_{2} / 95 \%$ air. The cells were passaged every $3 \mathrm{~d}$ and grown to $80 \%$ confluence. The mTagRFP-mWasabi-LC3 plasmid was a generous gift from Dr. Cuihong Zhou (Peking University, Beijing, China). Approximately $1.4 \times 10^{5}$ cells were plated into each well of a 24 -well plate $24 \mathrm{~h}$ before transfection. Plasmid ( $500 \mathrm{ng} /$ well) transfections were performed with Lipofectamine 2000 (11668; Invitrogen) according to the manufacturer's protocol. To study the effect of Se-Met on autophagic flux in N2a-sw cells, cells were pretreated with bafilomycin A1 (10, 50, 100, 200, or $400 \mathrm{~nm}) 4,8$, or 16 h before Se-Met treatment. The cells were treated with Se-Met for $24 \mathrm{~h}$.

Isolation of autophagic vacuoles and lysosomes from brain tissue. For each group, six different fresh hemibrains were pooled. Using a modified protocol from Marzella L (Marzella et al., 1982), the samples were homogenized and subjected to differential centrifugation. The nuclear fraction and any unbroken cells were precipitated; then, the fraction enriched in autophagic vacuoles, lysosomes, and mitochondria was collected (Cuervo et al., 1995; Yang et al., 2014). The different organelles in this fraction were isolated by flotation in a discontinuous gradient of Nycodenz (50, 26, 24, 20, and 10\%). A fraction containing mainly autophagosomes was recovered from the $10-20 \%$ interface, a fraction enriched in autolysosomes was isolated from the $20-24 \%$ interface, and a lysosome-enriched fraction was recovered from the $24-26 \%$ interface. These fractions were washed by centrifugation in $0.25 \mathrm{M}$ sucrose. Next, the pellets were homogenized in $3 \mathrm{vol}$ of TBS with a protease inhibitor mixture and phosphatase inhibitors (Roche), sonicated for $1 \mathrm{~min}$ in an ice bath, and centrifuged at $13,000 \times g$ for $30 \mathrm{~min}$ at $4^{\circ} \mathrm{C}$. The samples were then stored for subsequent Western blotting.

RNA isolation, cDNA synthesis, and RT-PCR for tauP301L mRNA. Total RNA was extracted from the hippocampi of AD mouse brains using TRIzol reagent. Total RNA $(2.5 \mu \mathrm{g})$ was reverse transcribed with an oligo dT primer in a $10 \mu \mathrm{l}$ volume using the PrimeScript first-strand cDNA synthesis kit (Takara Bio) according to the manufacturer's instructions. PCR was performed with 25 cycles of $1 \mathrm{~min}$ at $94^{\circ} \mathrm{C}, 1 \mathrm{~min}$ at $48^{\circ} \mathrm{C}$, and $2 \mathrm{~min}$ at $72^{\circ} \mathrm{C}$ in a $25 \mu \mathrm{l}$ reaction mixture containing $12.5 \mu \mathrm{l}$ of GoTag Green Master Mix (Promega), $0.5 \mu \mathrm{l}$ of the forward and reverse Tau5 primers (1 $\mu \mathrm{M}$ each) or $\beta$-actin primers (10 pM each), $0.5 \mu \mathrm{l}$ of first-strand cDNA, and $11 \mu \mathrm{l}$ of nuclease-free water. The primer sequences used were $5^{\prime}$-TCGCAGTCAC CGCCACCCAC-3' (forward) and 5'-TGTCATCGCTTCCAGTCCCG TC-3' (reverse) for tauP301L and 5'-GGAGAAGATCTGGCACCACA CC-3' (forward) and 5' -CCTGCTTGCTGATC CACATCTGCTGG-3' (reverse) for mouse $\beta$-actin. The $\beta$-actin primer was used as an internal control. Each PCR product $(10 \mu \mathrm{l}$ ) was run on a $2 \%$ agarose gel containing $0.1 \mu \mathrm{g} / \mathrm{ml}$ ethidium bromide, and the amplified products $(750 \mathrm{bp}$ for tauP301L and $840 \mathrm{bp}$ for $\beta$-actin) were visualized using an imaging system (G: Box; Syngene).

Transmission electron microscopy. Transmission electron microscopy was performed as described previously (Su et al., 2014; Jiang et al., 2015). Briefly, mouse hippocampi were fixed with $2.5 \%$ glutaraldehyde for $2 \mathrm{~h}$ at $4^{\circ} \mathrm{C}$ and $1 \%$ osmium tetroxide for $2 \mathrm{~h}$ at $4^{\circ} \mathrm{C}$. After washing three times in distilled water, samples were dehydrated in a graded ethanol series and embedded in epoxy resin. Next, the samples were ultrathin sectioned (DiATOME knife and Leica ultramicrotome), stained with $2 \%$ uranyl acetate and 2\% lead citrate, and analyzed using an FEI Tecnai G2 Spirit transmission electron microscope.

Statistical analysis. The data were analyzed using GraphPad Prism software. All data are expressed as the mean \pm SEM and considered statistically significant at a level of $p<0.05$. A repeated-measures ANOVA was 
A

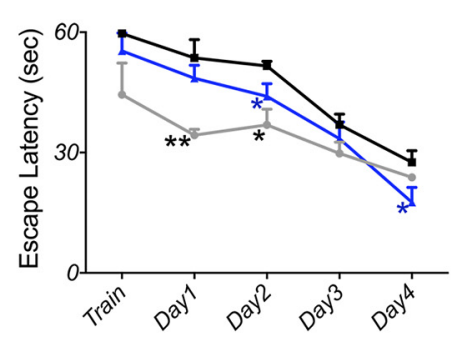

B

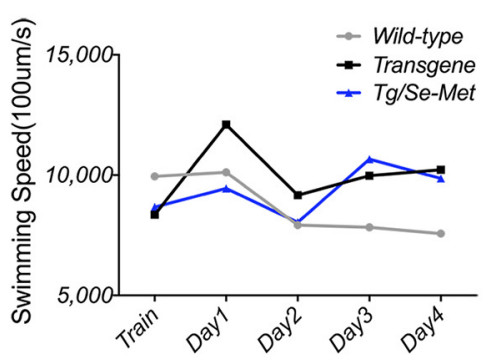

G
C

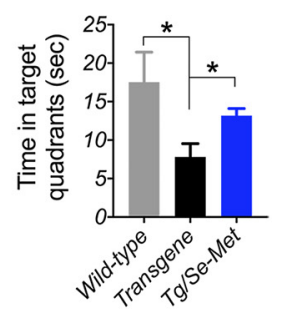

H

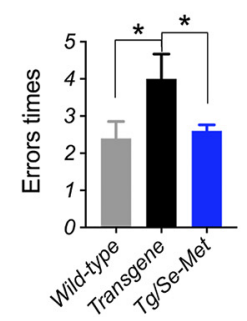

Figure 1. Se-Met administration ameliorates cognitive deficits in 3xTg-AD mice. $\boldsymbol{A}-\boldsymbol{F}$, The Morris water maze test was used to evaluate spatial memory in mice. $\boldsymbol{A}, \boldsymbol{B}$, During the $4 \mathrm{~d}$ of spatial orientation trials, escape latencies and swimming speed were measured to assess the memory and the locomotor ability of the mice, respectively. $\boldsymbol{C}-\boldsymbol{F}$, For the 24 and $72 \mathrm{~h}$ probe trials, respectively, the time spent in the target quadrant and the number of crossings over the original platform area were recorded. $\mathbf{G}, \boldsymbol{H}$, The latency period and number of errors during a step-down-type passive avoidance test were detected. The values are shown as the mean \pm SEM, and 12 mice were tested per group. ${ }^{*} p<0.05 ;{ }^{* *} p<0.01$.

used to analyze the behavioral test data. The one-way ANOVA and multiple comparisons test were used to analyze the immunoblot and RTPCR data.

\section{Results}

Se-Met rescues spatial memory deficits in 8-month-old 3xTg-AD mice

To examine the therapeutic efficacy of Se-Met, we used 8-monthold 3xTg-AD mice, which express mutant human APPswe, tauP301l, and mutant mouse PS1M146V. These mice along with age-matched WT mice were administered drinking water with Se-Met $(6 \mu \mathrm{g} / \mathrm{ml}, n=12)$ or nontreated water $(n=12)$ for 3 months, followed by behavioral analyses.

Spatial learning was assessed using the Morris water maze test, which measures the time required for mice to find the hidden platform (escape latency). A shorter escape latency was considered better spatial learning. We found that the escape latencies of the 3xTg-AD mice were markedly longer than those of WT mice. However, the prolonged latency was mostly reversed with Se-Met treatment (Fig. 1A). A $t$ test revealed that Se-Met-treated $3 \mathrm{xTg}-\mathrm{AD}$ mice performed significantly better than those of the control mice beginning on the second day (day 2 and day 4, $p<0.05$ ). Moreover, Se-Met-treated mice exhibited significantly shorter total escape latencies over 5 consecutive training days. No significant differences were observed in the swimming speed among the three groups (Fig. $1 A, B$ ), indicating that the effect of Se-Met on learning and memory was independent of physical performance.

Probe trials were conducted to evaluate the spatial reference memory of the mice 24 and $72 \mathrm{~h}$ after the $5 \mathrm{~d}$ training. The time spent in the target quadrant and the number of times the mice crossed the previous platform location during a single $60 \mathrm{~s}$ trial were measured. Twenty-four hours after training, 3xTg-AD mice spent significantly less time in the target quadrant than WT mice. Treatment with Se-Met significantly reversed this effect in transgenic mice $(p<0.05$; Fig. $1 C)$. In addition, Se-Met-treated mice swam across the platform location more frequently than the con- trol mice $(p<0.05$; Fig. $1 D)$. Similar results were obtained in the $72 \mathrm{~h}$ memory trial. Se-Met-treated 3xTg-AD mice spent more time in the target quadrant $(p<0.05$; Fig. $1 E)$. Se-Met-treated mice showed a trend toward increased platform crossings, but these data were not significantly different from those of the control mice (Fig. $1 F)$.

The step-down passive avoidance test was also used to evaluate the effect of Se-Met on the learning and memory of the transgenic mice. Compared with WT mice, $3 \times$ Tg-AD mice exhibited a poor performance consisting of a significant increase in the number of errors $(p<0.05$; Fig. $1 H)$ and a significant decrease in SDL $(p<0.05$; Fig. $1 G)$. Se-Met treatment did not significantly affect the SDL of 3xTg-AD mice, but the number of errors was significantly decreased. These findings suggest that Se-Met treatment effectively rescues the spatial memory deficits in 11-month-old $\mathrm{AD}$ mice.

\section{Se-Met reduces the accumulation of total tau and hyperphosphorylated tau}

Our previous work found that Se-Met ameliorated tau pathology in the brains of 4-month-old 3xTg-AD mice (Song et al., 2014). To determine whether Se-Met had a similar effect on older $3 \mathrm{xTg}-\mathrm{AD}$ mice when the integrated pathological features of tau have developed in the brain, the pathological changes of tau were investigated in the hippocampus and cortex, which represent the most sensitive regions affected in the AD brain (Bryan et al., 2009). After 3 months of treatment with Se-Met, Western blot analysis of total tau levels showed significant reductions in Trisbuffered saline (TBS)-soluble and TBS-insoluble tau in the hippocampus $(p<0.01$ and $p<0.05$, respectively; Fig. $2 A, B)$ and cortex $(p<0.05$ and $p<0.001$, respectively; Fig. $2 C, D)$ in SeMet-treated mice compared with untreated controls. Besides reducing total tau protein levels (P301L-tau, human full-length tau protein, about $55 \mathrm{kDa}$; Fig. 2), Se-Met treatment also decreased the levels of 35-45 kDa tau fragments, but the difference was not statistically significant (data not shown). The level of pS404-tau 
A

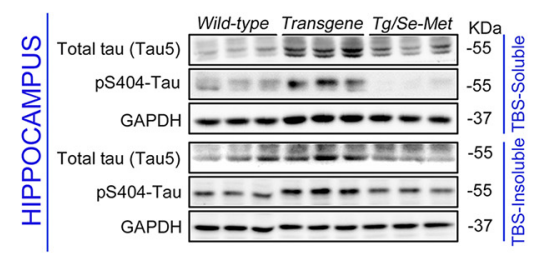

C

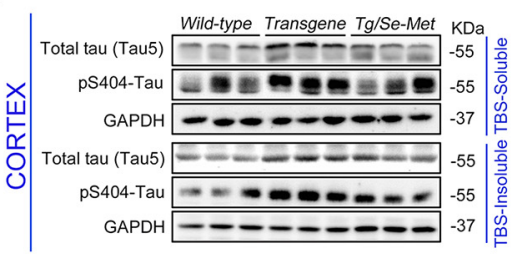

G

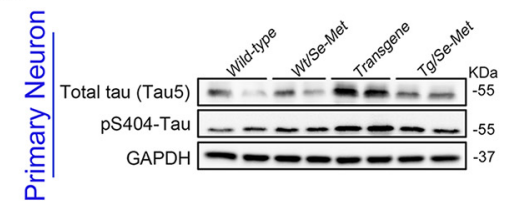

B

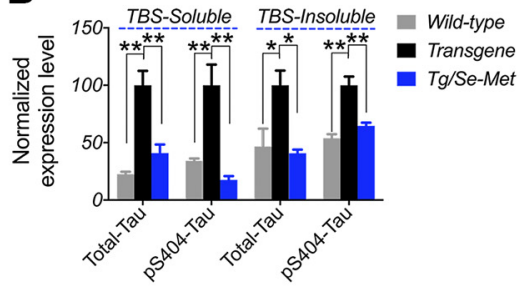

D

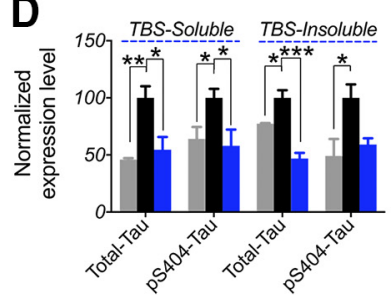

H

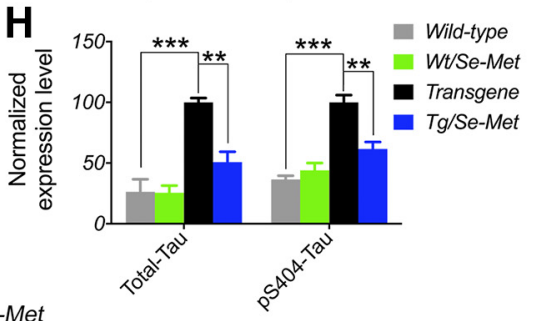

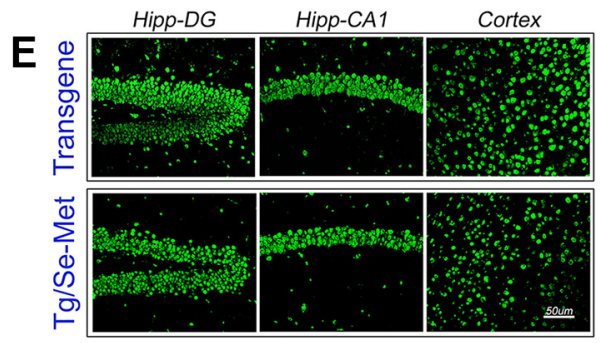

$\mathbf{F}$

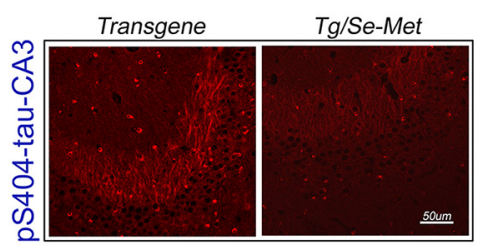

Transgene

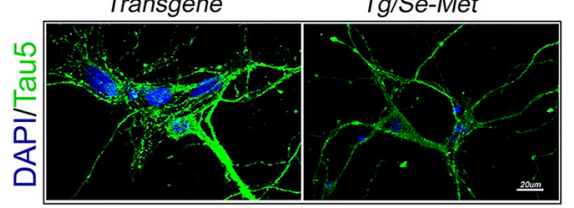

J

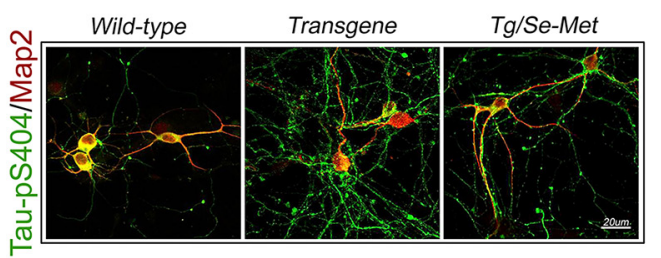

Figure 2. Se-Met decreases the level of total tau and hyperphosphorylated tau. $\boldsymbol{A}-\boldsymbol{D}$, Se-Met significantly reduced the levels of total tau and pS404-tau protein in the TBS-soluble and TBS-insoluble fractions of the hippocampus $(\boldsymbol{A}, \boldsymbol{B})$ and cortex $(\boldsymbol{C}, \boldsymbol{D})$ in $3 \mathrm{xTg}$-AD mice. $\boldsymbol{E}, \boldsymbol{F}$, Immunofluorescence images of tau in the hippocampus (DG and CA1) and cortex and pS404-tau in the hippocampus (CA3). $\mathbf{G}, \boldsymbol{H}$, Representative Western blot images and densitometric analysis of total tau and pS404-tau in primary cortical neurons. $\boldsymbol{I}, \boldsymbol{J}$, Immunofluorescence images of tau and pS404-tau in primary cortical neurons. Quantitative results were normalized against the levels of GAPDH. The data were expressed as percentages of the control (set to $100 \%$ ) and presented as the group mean $\pm \operatorname{SEM}(n=6) .{ }^{*} p<0.05 ;{ }^{* *} p<0.01 ;{ }^{* * *} p<0.001$. Scale bars, 20 and $50 \mu \mathrm{m}$. Hipp, Hippocampus; DG, dentate gyrus; CA1, cornu ammonis $1 ;$ CA3, cornu ammonis 3.

was also significantly decreased in the TBS-soluble and TBSinsoluble fractions from the hippocampus $(p<0.01$ and $p<$ 0.01 , respectively; Fig. $2 A, B)$ and TBS-soluble fractions from the cortex $(p<0.05$; Fig. $2 C, D)$ of Se-Met-treated mice. A histopathological analysis of total tau in the dentate gyrus, CA1 (cornu ammonis 1), and cortical regions of the brain revealed that Se-Met-treated mice showed markedly less tau immunostaining than control mice (Fig. 2E). Similarly, neuronal staining using a specific antibody against pS404-tau revealed lower fluorescence intensity in the hippocampus of Se-Met-treated mice than in control mice (Fig. $2 F$ ).

To further ascertain the effect of Se-Met on tau pathology, primary cortical neurons were isolated from newborn 3xTg-AD and WT mice. The neurons were treated with Se-Met $(1 \mu \mathrm{M})$ for $24 \mathrm{~h}$, and the levels of total tau and pS404-tau proteins were detected by Western blot. There was a significant increase in total tau and pS404-tau in primary 3xTg neurons compared with WT neurons ( $p<0.001$ and $p<0.001$, respectively; Fig. $2 G, H)$. Treatment with Se-Met significantly decreased the levels of both total tau and pS404-tau in 3xTg neurons $(p<0.01$ and $p<0.01$, respectively; Fig. $2 G, H$ ). Consistent with the immunoblot results, decreased fluorescence staining of tau5 and pS404-tau was observed in Se-Met-treated 3xTg neurons compared with the control group (Fig. $2 I, J$ ). Thus, Se-Met impedes tau pathology by decreasing total tau and tau hyperphosphorylation both in vitro and in vivo.

\section{Akt and GSK3 $\beta$ are involved in Se-Met-induced tau} dephosphorylation in aged $3 \times \mathrm{Tg}-\mathrm{AD}$ mice

To investigate the mechanisms underlying the effect of Se-Met on tau phosphorylation, several enzymes that regulate this posttranslational modification were evaluated. GSK3 $\beta$ is a major kinase that regulates tau hyperphosphorylation, and its activity is inhibited by phosphorylation at residue Ser9 (Hernandez et al., 2013). Thus, the levels of GSK $3 \beta$ and GSK3 $\beta$ phosphorylated at Ser9 $(\mathrm{p}-\mathrm{GSK} 3 \beta)$ were assessed by Western blot. The ratio of p-GSK $3 \beta / G S K 3 \beta$ inversely reflects the activity of GSK $3 \beta$ in vivo. Compared with WT mice, the ratio of $\mathrm{p}-\mathrm{GSK} 3 \beta / \mathrm{GSK} 3 \beta$ significantly decreased in the hippocampus and cortex of $3 \times \mathrm{Tg}-\mathrm{AD}$ mice $(p<0.05$ and $p<0.05$, respectively; Fig. $3 A-D)$. Se-Met significantly increased the ratio of $\mathrm{p}-\mathrm{GSK} 3 \beta / \mathrm{GSK} 3 \beta$ in the hippocampus and cortex $(p<0.001$ and $p<0.05$, respectively; Fig. $3 A-D)$, suggesting that Se-Met inhibits GSK3 $\beta$ activity in $3 \mathrm{xTg}-\mathrm{AD}$ mice. PP2A is part of a large family of enzymes that accounts for the majority of Ser/Thr phosphatase activity in the brain and a major tau phosphatase in vivo (Sontag and Sontag, 2014). PP2A is inactivated by phosphorylation at Tyr-307. The ratio of $\mathrm{p}-\mathrm{PP} 2 \mathrm{~A} / \mathrm{PP} 2 \mathrm{~A}$ significantly decreased in the hippocam- 
A

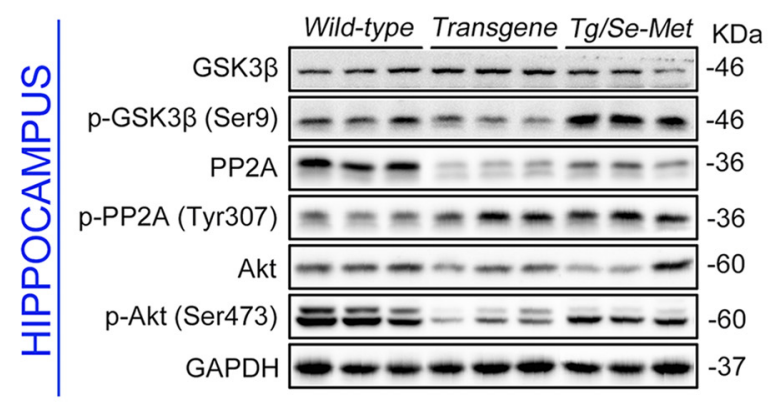

C

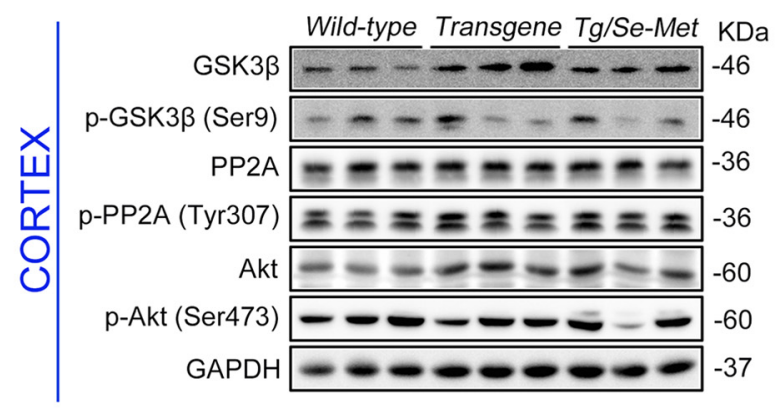

E

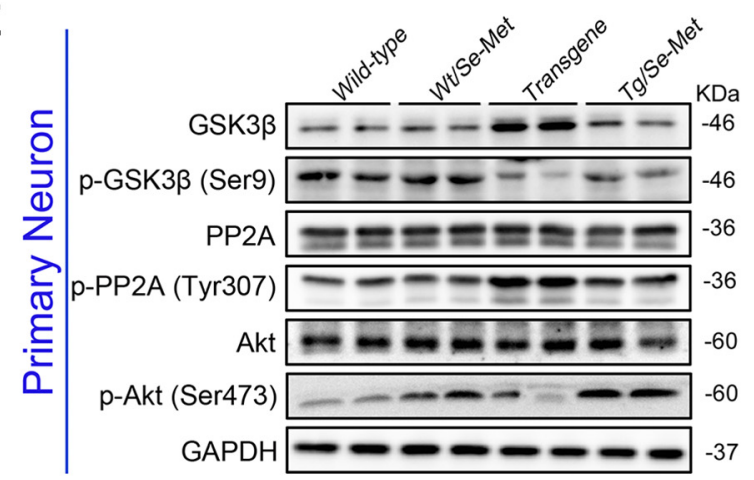

B

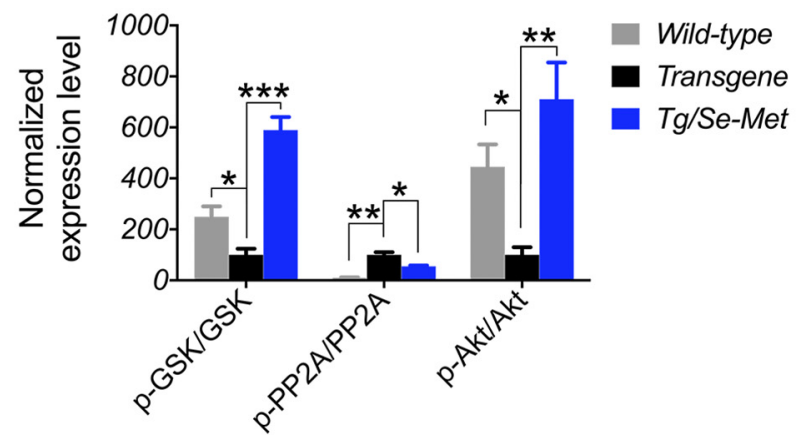

D

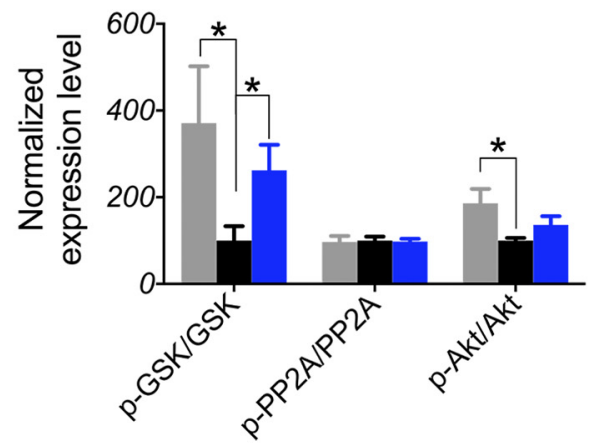

F

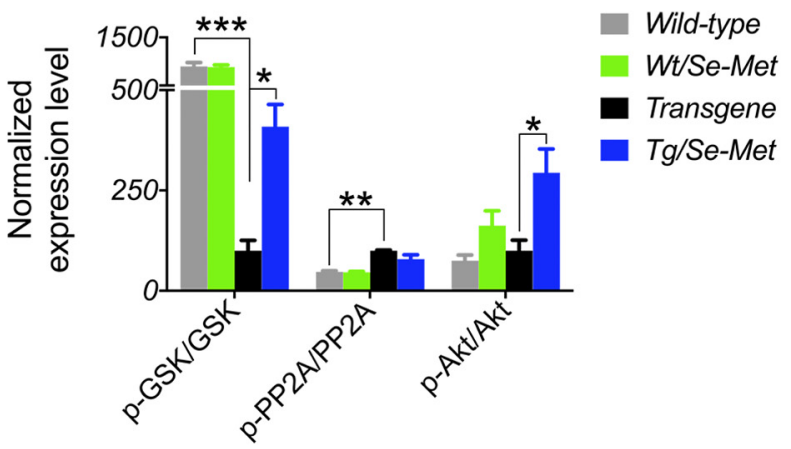

Figure 3. Se-Met decreases tau phosphorylation via activation of Akt and inhibition of GSK3 $\beta . A, B$, Representative Western blot images and quantification of GSK3 $\beta$, pGSK3 $\beta$ (Ser9), PP2A, p-PP2A (Tyr307), Akt, and p-Akt (Ser473) in the hippocampus of WT, Se-Met-treated, and control mice. C, D, Representative Western blot images and analysis of these kinases in the cortex of WT, Se-Met-treated, and control mice. $\boldsymbol{E}, \boldsymbol{F}$, Western blot images and analysis of these kinases in primary cortical neurons. Densitometry results were normalized against the levels of GAPDH. The values are expressed as percentages of the control (set to $100 \%)$ and presented as the group mean $\pm \operatorname{SEM}(n=6) .{ }^{*} p<0.05 ;{ }^{* *} p<0.01$.

pus of 3xTg-AD mice after the treatment of Se-Met $(p<0.05$, Fig. $3 A, B)$. However, there was no difference in the ratio of p-PP2A/PP2A in the cortex among WT, Se-Met-treated, and control groups. Akt is an important upstream protein kinase that can promote the phosphorylation of GSK3 $\beta$ at Ser9 (Dolan and Johnson, 2010). Similarly, Akt can be activated by phosphorylation at Ser473, and the ratio of p-Akt/Akt reflects Akt activity. The ratio of p-Akt/Akt significantly decreased in the hippocampus and cortex of $3 \mathrm{xTg}-\mathrm{AD}$ mice compared with WT mice $(p<0.05$ and $p<0.05$, respectively; Fig. $3 A-D)$, and Se-Met treatment significantly increased $\mathrm{p}$-Akt/Akt in the hippocampus $(p<0.01$; Fig. $3 A, B)$.

We also examined these enzyme levels in primary cortical neurons using Western blotting. Se-Met had no significant effect on the activities of those enzymes in WT neurons. The ratio of $\mathrm{p}-\mathrm{GSK} 3 \beta /$ GSK $3 \beta$ significantly decreased and the ratio of p-PP2A/PP2A significantly increased in 3xTg neurons compared with WT neurons $(p<$ 0.001 and $p<0.01$, respectively; Fig. $3 E, F)$. Similar to the in vivo results, Se-Met treatment significantly improved the p-GSK3 $\beta$ / GSK $3 \beta$ and $p$-Akt/Akt ratios $(p<0.05$ and $p<0.05$, respectively; Fig. $3 E, F)$ and had no effect on the p-PP2A/PP2A ratio.

\section{Se-Met promotes tau clearance by modulating the} AMPK-mTOR-mediated autophagic pathway

The decrease in total tau could be the result of inhibition of the transcription and translation of P301L-tau gene or the elimination of abnormal tau proteins. We found no significant difference in the level of tau mRNA between Se-Met-treated and control 
A

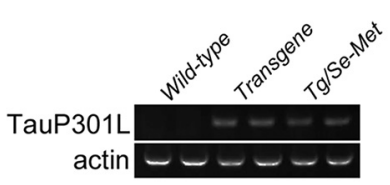

C

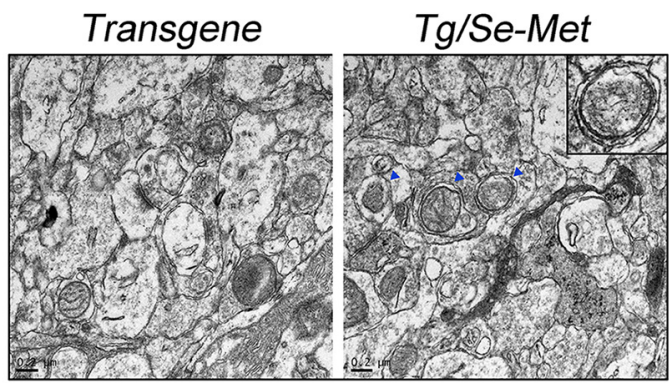

Figure 4. Se-Met has no effect on tau P301L transcription and increases the formation of autophagosomes in the hippocampus of 3xTg-AD mice. $\boldsymbol{A}, \boldsymbol{B}$, The level of tauP301L mRNA in the hippocampus was investigated by RT-PCR. Quantitative results were normalized against the level of actin. Values are expressed as percentages of the control (set to 100\%) and presented as the group mean \pm SEM $(n=4)$. C, The double-membrane-bound autophagosomes in the hippocampus of 3xTg-AD mice were observed using transmission electron microscopy. Scale bars, $0.2 \mu \mathrm{m}$.

mice (Fig. 4A,B), which implied that the reduction in tau was attributable to a clearance mechanism. Thus, we next focused on the autophagic pathway. Autophagy, a vital catabolic process in cells, is a primary driving force for degradation of abnormal and aggregated proteins and an essential protective response to pathologic stress. Light chain protein 3 (LC3) is a commonly used marker of autophagy. This protein is converted from its inactive LC3-I form to active LC3-II during formation of the autophagosome. To assess autophagy after Se-Met treatment, LC3-II in the brain was detected by Western blotting. LC3-II in the hippocampus and cortex of 3xTg-AD mice was significantly lower compared with WT mice $(p<0.05$ and $p<0.05$, respectively; Fig. $5 A-D)$. However, this effect was significantly attenuated in Se-Met-treated mice ( $p<0.05$ and $p<0.05$, respectively; Fig. $5 A-D)$. Consistent with the immunoblot results, transmission electron microscopy revealed more autophagosomes in the cytoplasm of hippocampal neurons from Se-Met-treated mice than control mice (Fig. 4C). Collectively, these results suggest that Se-Met promotes the initiation of autophagy to enhance tau clearance.

$\mathrm{mTOR}$, a serine/threonine protein kinase, is a major regulator of mammalian autophagy (Schmelzle and Hall, 2000). Both the hippocampus and cortex of 3xTg-AD mice showed significantly increased mTOR $(p<0.01$ and $p<0.05$, respectively; Fig. $5 A-D)$ and p-mTOR (Ser2448; $p<0.05$ and $p<0.05$, respectively; Fig. $5 A-D)$ levels compared with WT mice, and treatment with SeMet significantly reduced levels of $\operatorname{mTOR}(p<0.01$ and $p<0.05$, respectively; Fig. $5 A-D)$ and $\mathrm{p}-\mathrm{mTOR}(p<0.001$ and $p<0.05$, respectively; Fig. $5 A-D$ ) in both hippocampus and cortex. mTOR activity is routinely measured by the phosphorylation level of its direct downstream target p70S6K at Thr389. After treatment with Se-Met, the levels of p70S6K and p-p70S6K in the hippocampus were significantly decreased compared with control mice $(p<0.01$ and $p<0.05$, respectively; Fig. $5 A-D)$. In addition to $\mathrm{mTOR}, \mathrm{AMPK}$ plays a significant role in the promotion of autophagy. When activated by phosphorylation at Thr172, AMPK inhibits mTOR activation. The levels of AMPK (in the hippocampus) and p-AMPK (in the cortex) were significantly decreased in the brain of 3xTg-AD mice compared with WT mice $(p<0.05$ and $p<0.01$, respectively; Fig. $5 A-D)$. Treatment with Se-Met significantly increased AMPK (in the hippocampus; $p<0.5$; Fig. $5 A, B)$ and p-AMPK (in the hippocampus and cortex; $p<0.001$ and $p<0.01$, respectively; Fig. $5 A-D)$. To validate the relationship between tau clearance and autophagy, the localization of LC3-II and total tau in the hippocampus was determined using immunofluorescence (Fig. 5E). Se-Met reduced the intensity of total tau fluorescence, increased the fluorescence intensity of LC3-II, and increased the colocalization of LC3-II with tau.

A similar phenomenon was observed in primary cortical neurons. The level of LC3-II in 3xTg neurons was significantly lower than in WT neurons $(p<0.05$; Fig. $5 F, G)$, and Se-Met treatment significantly restored the level of LC3-II in 3xTg neurons $(p<0.05$; Fig. $5 F, G)$. The expression of mTOR and $\mathrm{p}-\mathrm{mTOR}$ in $3 \mathrm{xTg}$ neurons was significantly higher than in WT neurons $(p<0.01$ and $p<0.05$, respectively; Fig. $5 F, G)$. Treatment with Se-Met significantly inhibited $\mathrm{mTOR}$ and $\mathrm{p}-\mathrm{mTOR}$ expression $(p<0.05$ and $p<0.01$, respectively; Fig. $5 F, G$ ). Se-Met treatment also reversed the increased expression of p70S6K and p-p70S6K $(p<0.01$ and $p<0.01$, respectively; Fig. $5 F, G)$ and improved the level of p-AMPK $(p<0.05$; Fig. $5 F, G)$ in $3 \times$ Tg neurons. These data suggest that Se-Met promotes the clearance of tau protein by regulating the AMPK-mTOR-mediated autophagic pathway.

\section{Se-Met enhances the degradation of p62 and increases cathepsin D levels in the autophagy-lysosomal pathway}

Defects in autophagic maturation may be a general feature of $\mathrm{AD}$ pathology. p62/SQSTM1 is involved in the targeting of ubiquitinated proteins to autophagic vacuoles and has been identified as one of the specific substrates that are degraded through the autophagy-lysosomal pathway. Since the expression of p62 is inversely correlated with autophagic activity (Komatsu et al., 2007; Mizushima et al., 2010), we assessed p62 levels by Western blotting. The 3xTg-AD mice showed significantly increased p62 expression compared with WT mice (hippocampus, $p<0.01$; cortex, $p<0.01$; Fig. $6 A-D)$. Treatment with Se-Met significantly reduced p62 levels (hippocampus, $p<0.05$; cortex, $p<0.01$; Fig. $6 A-D)$. Cathepsin D (CatD), a principal lysosomal aspartyl protease, is highly abundant in the brain and is activated by proteolysis in the acidified lysosome to produce a mature proteolytic product (mCatD) (Avrahami et al., 2013). Precursor CatD $(46-52 \mathrm{kDa})$ and $\mathrm{mCatD}(32 \mathrm{kDa})$ were detected in the brains of WT, Se-Met-treated, and 3xTg-AD mice. The expression of mCatD was significantly reduced in $3 \mathrm{xTg}-\mathrm{AD}$ mice compared with WT mice (hippocampus, $p<0.01$; cortex, $p<0.01$; Fig. $6 A-D)$. Treatment with Se-Met significantly elevated mCatD expression in the hippocampus and cortex of 3xTg-AD mice (hippocampus, $p<0.05$; cortex, $p<0.01$; Fig. $6 A-D$ ). Immunofluorescence staining of CatD in the hippocampus and cortex of the brain revealed that the Se-Met-treated group showed a 
A

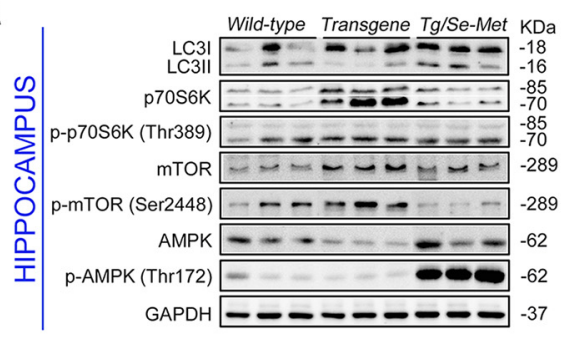

C

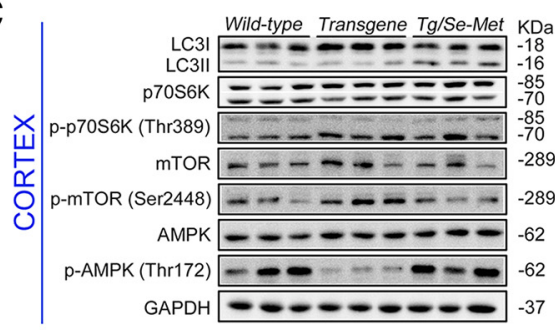

$\mathbf{F}$

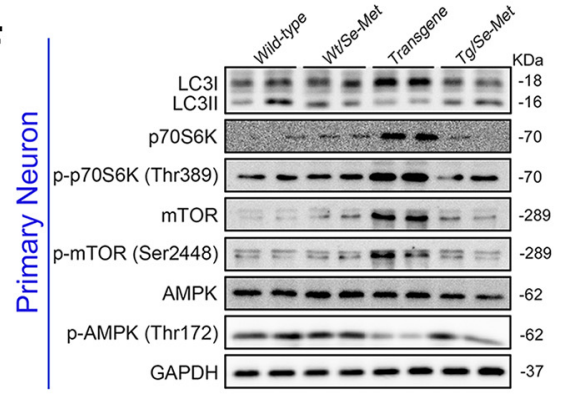

B

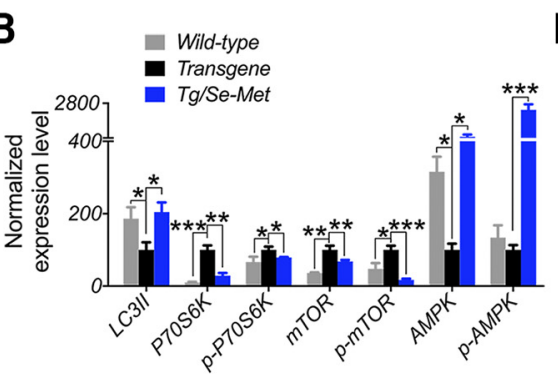

D

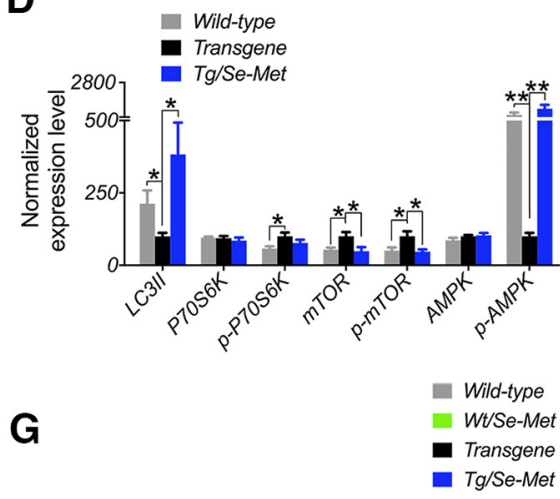

E
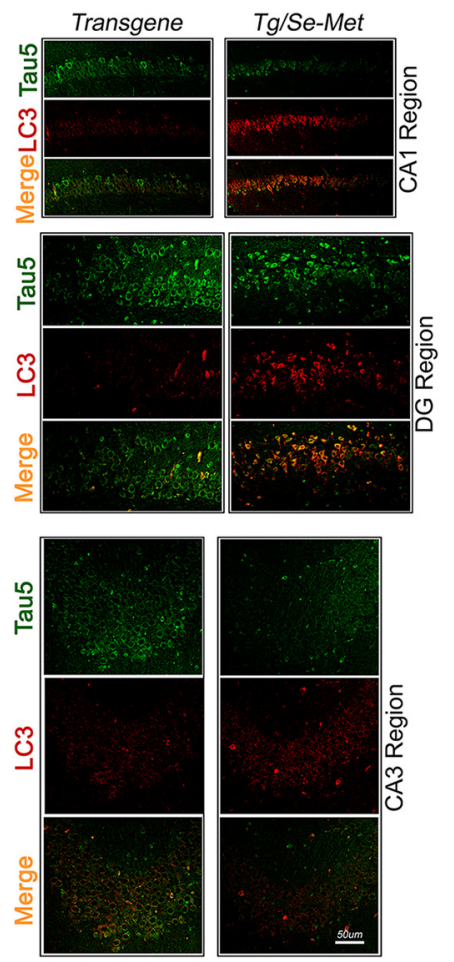

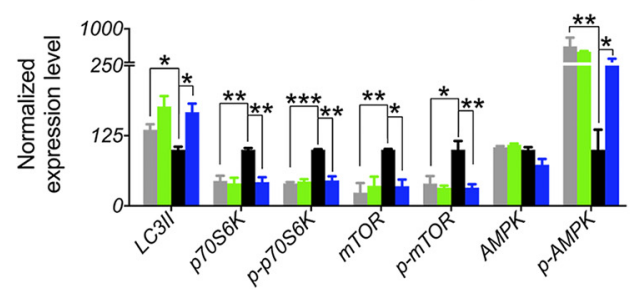

Figure 5. Se-Met enhances tau clearance by promoting the initiation of autophagy via the AMPK-mTOR pathway. $A, B$, Representative Western blot images and densitometric analysis of LC3-II, mTOR, p-mTOR (Ser2448), p7056K, p-p70S6K (Thr389), AMPK $\alpha$, and pAMPK $\alpha$ (Thr172) expression in the hippocampus of WT, Se-Met-treated, and control mice. C, D, Representative Western blot images and densitometric analysis of these kinases in the cortex of WT, Se-Met-treated, and control mice. $\boldsymbol{E}$, Immunofluorescence staining was performed to detect the expression and localization of LC3 and total tau in the hippocampus (DG, CA1, and CA3). $F$, G, Representative Western blot images and densitometric analysis of LC3-II, mTOR, p-mTOR (Ser2448), p70S6K, p-p70S6K (Thr389), AMPK $\alpha$, and pAMPK $\alpha$ (Thr172) in primary cortical neurons. Densitometry results were normalized against the levels of GAPDH. Values are expressed as percentages of the control (set to $100 \%)$ and presented as the group mean \pm SEM $(n=6) .{ }^{*} p<0.05 ;{ }^{* * *} p<0.01 ;{ }^{* * *} p<0.001$. Scale bar, $50 \mu \mathrm{m}$. DG, Dentate gyrus; CA1, cornu ammonis 1 ; CA3, cornu ammonis 3.

marked increase in CatD-positive area compared with the control group (Fig. 6E). Similar phenomena were observed in the primary cortical neurons. Se-Met treatment significantly inhibited the p62 level $(p<0.001$; Fig. $6 F, G)$ and increased mCatD expression $(p<0.05$; Fig. $6 F, G)$ in $3 \times$ Tg neurons.

Se-Met enhances autophagic proteolysis and autophagic flux LC3-II first appears on newly formed autophagosomes and is then quickly degraded by lysosomal enzymes after autophagolysosomal fusion. To investigate whether autophagic proteolysis and protein turnover can be restored by Se-Met treatment, lysosomes and autophagic vacuoles of relatively lower (autophagosome) and higher (autolysosome) density were isolated from the brains of three groups of mice by subcellular fractionation using a Nycodenz density gradient. The identities of these organelles were verified by the presence of LC3-II and/or LAMP1 (a marker for lysosome) immunoreactivity using immunoblot analyses (Fig. 7A). The lysosome fractions of 3xTg-AD mice contained abnormally low levels of LC3-II compared with WT mice. Levels of p62 were higher in the autophagosome fraction and decreased in the autolysosome fraction in 3xTg-AD mice. After treatment with Se-Met, the levels of p62 in both fractions were restored to WT levels (Fig. 7A).

Additional immunoblot analyses of these subcellular fractions using anti-tau/pS404-tau antibodies revealed increased tau protein accumulation within the lysosomal compartments of WT and Se-Met-treated mice compared with 3xTg-AD mice (Fig. $7 A, B$ ). Interestingly, pS404-tau levels were increased in the autophagosome and decreased in the autolysosome in 3xTg-AD mice. Se-Met treatment potently restored pS404-tau levels in these fractions to WT levels (Fig. $7 A, C$ ).

Based on these data, a N2a cell line overexpressing mutant human swedish-APP695 was treated with bafilomycin A1. Bafilomycin $\mathrm{A} 1$ is an autophagic flux inhibitor that blocks the fusion of autophagosomes with the lysosome, thereby inhibiting the autophagic degradation of proteins, including LC3-II and p62. The optimal concentration and treatment time with bafilomycin A1 were determined to be $50 \mathrm{~nm}$ and $4 \mathrm{~h}$, respectively (data not shown). The ratio of LC3-II/LC3-I was significantly increased by blocking the transformation of the autophagosome to the autoly- 
A

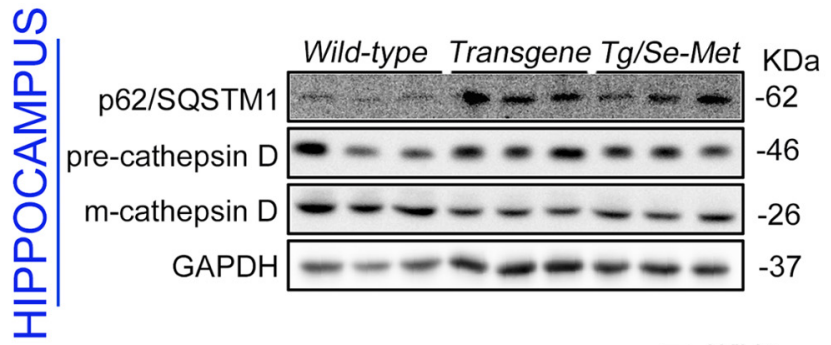

B

C

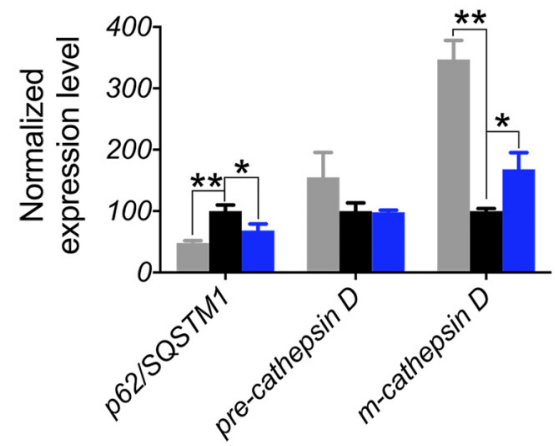

F
E

Wild-type

- Transgene

- Tg/Se-Met
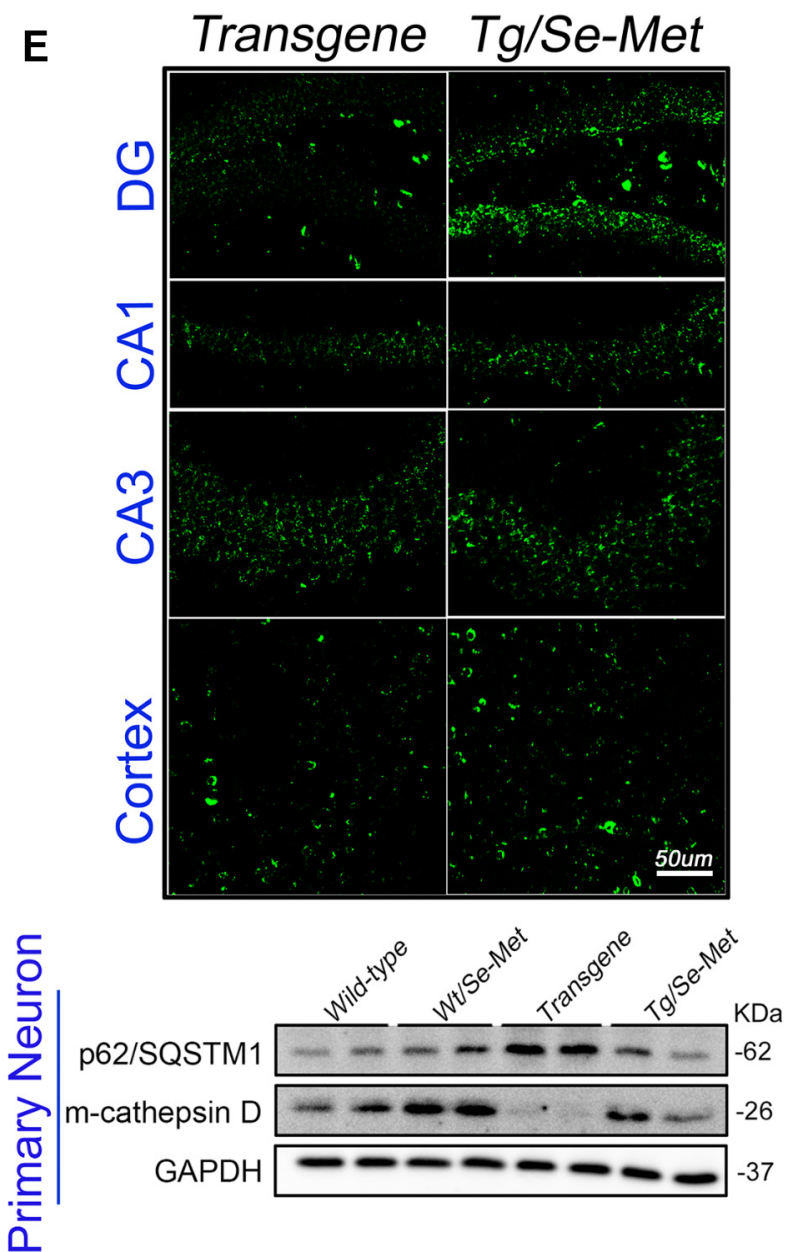

D

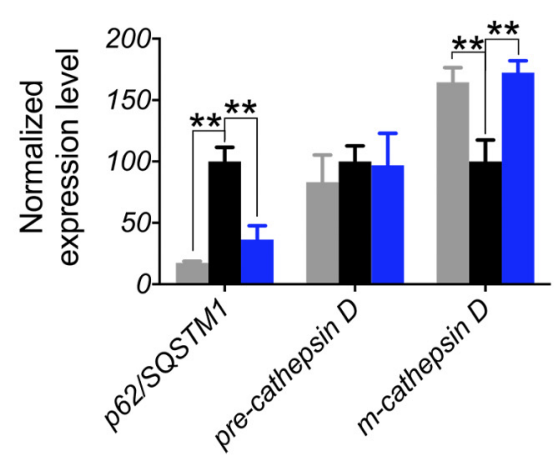

G

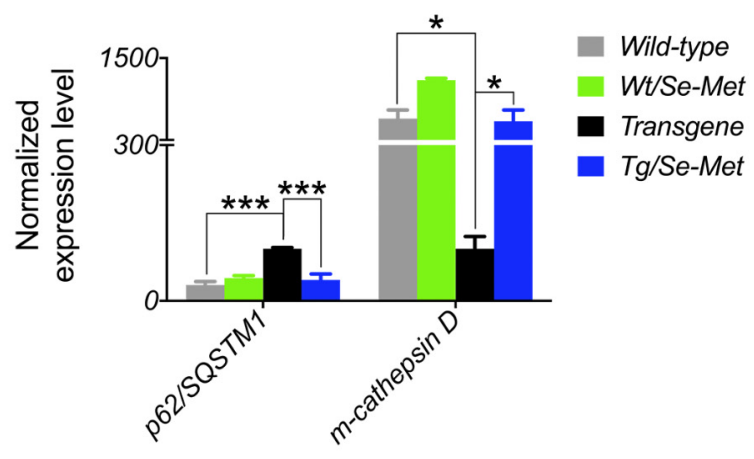

Figure 6. Se-Met decreases p62 protein expression and increases cathepsin D protein expression. $\boldsymbol{A}-\boldsymbol{D}$, Representative Western blot images of p62 and CatD expression in the hippocampus $(\boldsymbol{A}, \boldsymbol{B})$ and cortex $(\boldsymbol{C}, \boldsymbol{D})$ of WT, Se-Met-treated, and control mice. $\boldsymbol{E}$, Immunofluorescence staining of CatD in the hippocampus (DG, CA1, and CA3) and cortex. $\boldsymbol{F}, \boldsymbol{G}$, Representative Western blot images of $p 62$ and CatD expression in primary cortical neurons. Densitometry results were normalized against the levels of GAPDH. Values are expressed as percentages of the control (set to 100\%) and presented as the group mean $\pm \operatorname{SEM}(n=6) .{ }^{*} p<0.05 ;{ }^{* *} p<0.01$. Scale bar, $50 \mu \mathrm{m}$. DG, Dentate gyrus; CA1, cornu ammonis 1; CA3, cornu ammonis 3.

sosome with bafilomycin A1 $(p<0.001$; Fig. $8 A, B)$. Cotreatment of bafilomycin A1 with Se-Met significantly inhibited the bafilomycin A1-induced increase in LC3-II/LC3-I $(p<0.05$; Fig. $8 A, B$ ). Immunofluorescence staining of LC3 (Fig. $8 C$ ) confirmed that $\mathrm{Se}-\mathrm{Met}$ restored autophagic degradation.

We also used an improved tandem fluorescent-tagged LC3 (mTagRFP-mWasabi-LC3) to monitor autophagic flux based on the different $\mathrm{pH}$ stabilities of green and red fluorescent proteins. The acidic environment (less than $\mathrm{pH} 5$ ) inside the lysosome quenches the fluorescent signal of mWasabi but exerts a weak effect on mRFP. In green/red merged images, yellow puncta (i.e., $\mathrm{RFP}^{+} \mathrm{mWasabi}^{+}$) indicate autophagosomes, whereas red puncta (i.e., $\mathrm{RFP}^{+} \mathrm{mWasabi}^{-}$) indicate autolysosomes (Zhou et al., 2012). Thus, autophagic flux is increased when the presence of both yellow and red puncta is increased in the cells, and autophagic flux is blocked when only the presence of yellow puncta is increased in cells (Zhou et al., 2012). The mTagRFP-mWasabi-LC3 plasmid was transfected 
B

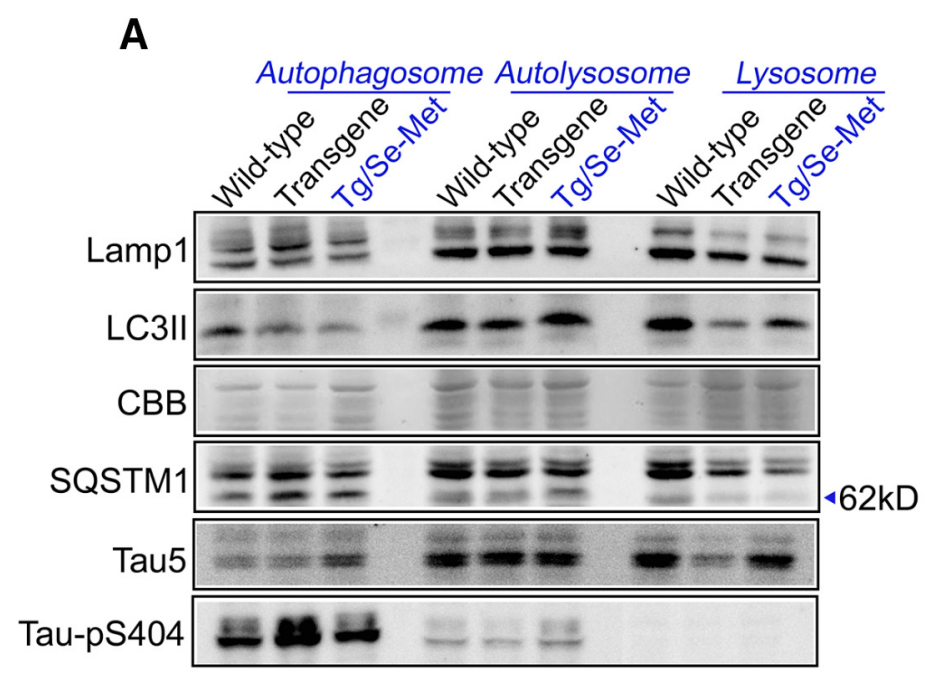

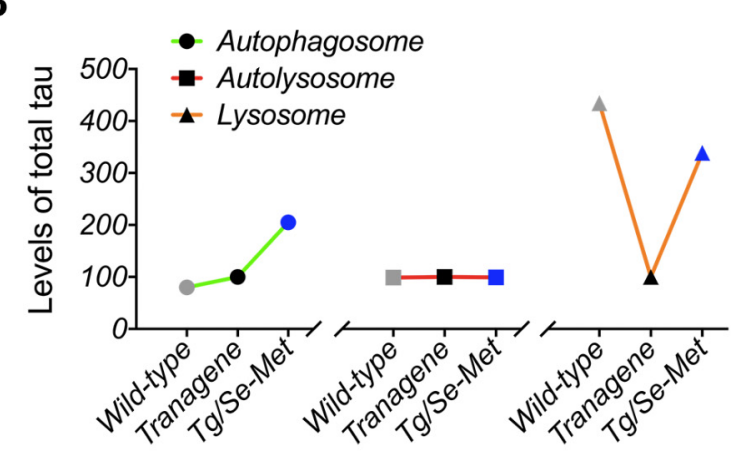

C

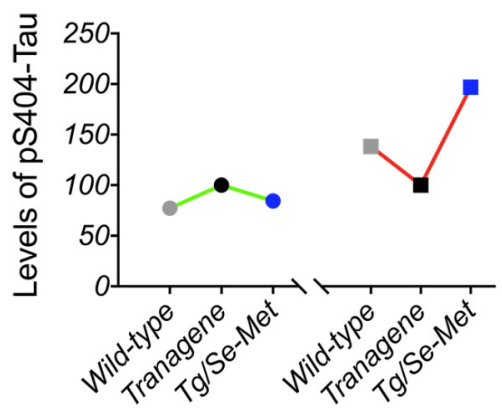

Figure 7. Se-Met influences the levels of total tau and phosphorylated tau in the autolysosome, autolysosome, and lysosome fractions isolated from the brain of $3 \times$ Tg-AD mice. $\boldsymbol{A}$, Autophagosome, autolysosome, and lysosome fractions were isolated from the brain of WT, Se-Met-treated, and control mice. The relative enrichment of autophagic and lysosomal protein markers was detected by Western blot with anti-LC3 and anti-Lamp1 antibodies (top two rows), respectively. The expression of p62, total tau, and phosphorylated tau in these fractions was detected (bottom three rows). $\boldsymbol{B}, \boldsymbol{C}$, Densitometry analysis of total tau $(\boldsymbol{B})$ and phosphorylated tau $(\boldsymbol{C})$ expression in different fractions. CBB, Coomassie Brilliant Blue.

into N2a-sw cells, followed by treatment with bafilomycin A1 and/or Se-Met. Bafilomycin A1 treatment markedly increased the number of yellow puncta in cells, whereas the cotreatment with bafilomycin A1 and Se-Met notably improved the number of yellow and red puncta in the cells compared with bafilomycin A1 treatment only (Fig. 8D). These data indicate that Se-Met modulates autophagic flux to promote autophagic proteolysis.

\section{Discussion}

Se is widely recognized as an essential trace element and an abundant micronutrient in the brain. Evidence suggests that Se levels in the brain decrease with age and are associated with a decline of cognitive function in AD patients (Gao et al., 2007, 2012). Thus, Se is vital for central neuron system function. Se supplementation significantly enhanced mitochondrial function and protected cells from apoptosis in primary neurons; in addition, the treatment reduced $\mathrm{A} \beta$ production, mitigated tau pathology, and ameliorated cognitive deficits and oxidative damage in $\mathrm{AD}$ animal models (Gwon et al., 2010; van Eersel et al., 2010; Mendelev et al., 2012). Se-Met, the predominant chemical form of Se ingested by humans, delayed the decline in cognitive function, reduced tau hyperphosphorylation, and ameliorated synaptic deficits in 4-month-old 3xTg-AD mice (Song et al., 2014). The principal pathological hallmarks (e.g., hyperphosphorylation of tau, $A \beta$ deposition, and inflammation) were significantly increased in the hippocampus and cortex of 8 -month-old 3xTg-AD mice. Thus, determining the effect of Se-Met in aged $\mathrm{AD}$ mice is important because $\mathrm{AD}$ is not diagnosed in patients until advanced stages. In our present study, 8-month-old 3xTg-AD mice were treated with $6 \mu \mathrm{g} / \mathrm{ml} \mathrm{Se}-\mathrm{Met}$ in their drinking water for 12 weeks to explore its effect on the phenotype, especially tau pathology. We demon- strated that long-term treatment with Se-Met reduced tau hyperphosphorylation by regulation of the Akt/GSK3 $\beta$ pathway and cleared tau protein by the AMPK-mTOR-mediated autophagic pathway. Furthermore, Se-Met ameliorated the cognitive impairment in older 3xTg-AD mice. Our results provide the first evidence for the effect of Se on autophagy in neurodegenerative disease.

Tau is mainly expressed in neurons and is abundant in neuronal axons (Z. Zhang et al., 2014). Normal post-translational phosphorylation of tau controls microtubule dynamics and establishes neuronal polarity, axonal outgrowth, and axonal transport. Pathological hyperphosphorylated tau, the main component of NFTs in AD, severely interferes with tau's ability to regulate microtubules dynamics (Caceres and Kosik, 1990; Harada et al., 1994), displays an increased propensity to form paired helical filaments in vitro, and sequesters full-length tau and other microtubule-associated proteins (Alonso et al., 2001). As expected, Se-Met reduced the hyperphosphorylation of tau in 11-month-old 3xTg-AD mice (after a 3-month treatment). These data suggest that Se-Met has a significant therapeutic effect on tauopathy. An imbalanced regulation in protein kinases and protein phosphatases is the direct cause for tau hyperphosphorylation in $\mathrm{AD}$. As the kinase and phosphatase playing key roles in the regulation of tau phosphorylation, GSK3 $\beta$ phosphorylates tau at multiple AD-related sites in a site-specific manner (Hanger et al., 2009) and PP2A accounts for $\sim 70 \%$ of the total tau phosphatase activity in the brain and plays a dominant role in the regulation of tau dephosphorylation. Se-Met significantly inhibited the activity of GSK3 $\beta$ and increased that of PP2A in aged 3xTg-AD mice. This result can be explained by the dynamic cross talk between GSK $3 \beta$ and PP2A at different stages of AD. Indeed, these proteins are regulated by each other and control tau phosphorylation both directly and indirectly 
A

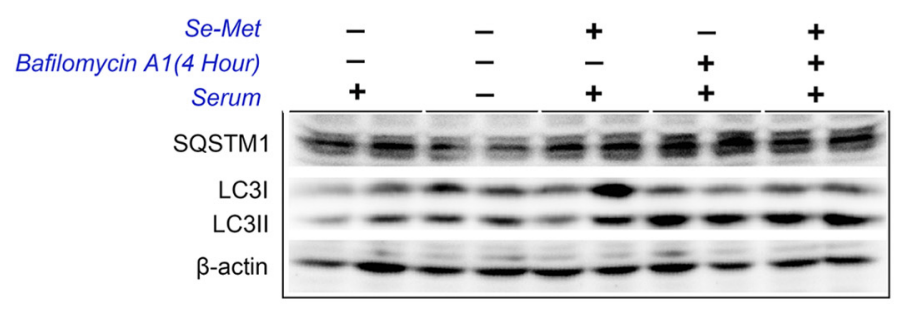

B

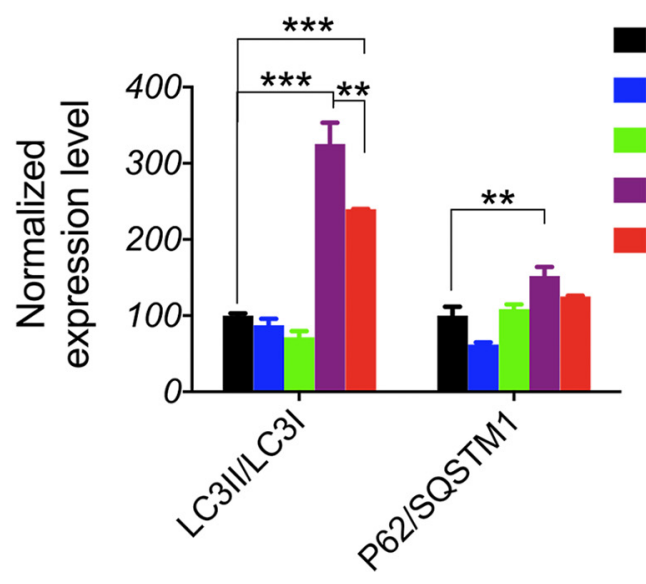

C

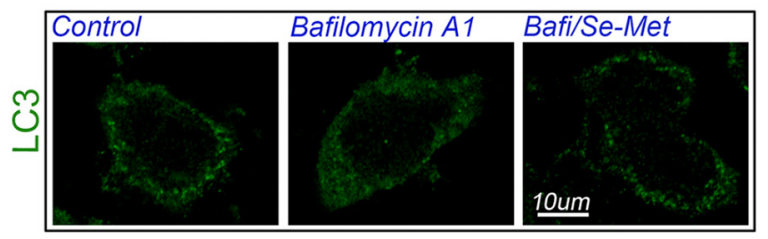

D

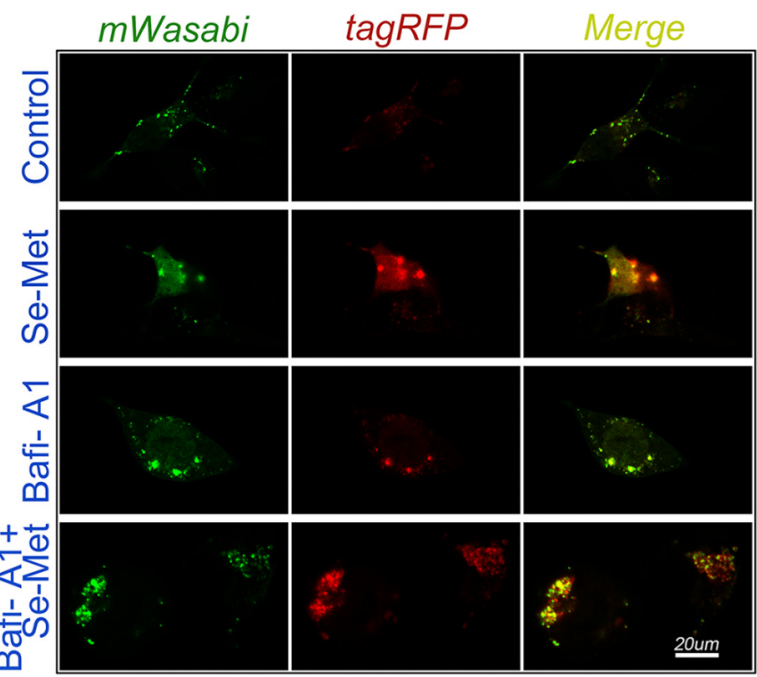

Figure 8. Se-Met enhances autophagic flux by promoting autophagolysosomal fusion. N2a-sw cells were treated with bafilomycin $\mathrm{A} 1$ ( $50 \mathrm{~nm}, 4 \mathrm{~h}$ ) to block the fusion of autophagosomes with lysosomes, and the effect of Se-Met (1 $\mu \mathrm{m}$ ) on autophagic flux was assessed. $\boldsymbol{A}, \boldsymbol{B}$, The expression of $\mathrm{p} 62$ and $\mathrm{LC} 3 \mathrm{ll}$ was detected by Western blot. Quantitative results were normalized against the levels of $\beta$-actin. Values are expressed as percentages of the control (set to 100\%) and presented as the group mean \pm SEM $(n=3)$. ${ }^{*} p<0.05$; ${ }^{* *} p<0.01 ;{ }^{* * *} p<0.001$. C, LC 3 expression was detected by immunofluorescence staining in N2a-sw cells. $\boldsymbol{D}$, Representative fluorescent images of N2a-sw cells transiently transfected with mTagRFP-mWasabi-LC3, followed by bafilomycin A1 and/or Se-Met treatment. Scale bars, 10 and $20 \mu \mathrm{m}$.

(Wang et al., 2015). The activity of Akt, the most important upstream kinase that phosphorylates GSK3 $\beta$ at Ser9, was significantly increased after Se-Met treatment. This suggests Se-Met reduces tau hyperphosphorylation by promoting Akt activity, which subsequently inhibits GSK3 $\beta$ activity.

Although hyperphosphorylation is a potent inducer of tau pathology, tau-mediated neurodegeneration in $\mathrm{AD}$ may result from the combination of toxic gain of function in pathological tau (abnormal or aggregated forms) and loss of function in normal tau (Ballatore et al., 2007). Tau hyperphosphorylation at specific sites reduces its ability to bind microtubules and markedly promotes self-aggregation (Liu et al., 2007). Mutant human $\mathrm{P} 301 \mathrm{~L}-\mathrm{tau}$ is overexpressed in $3 \mathrm{xTg}-\mathrm{AD}$ mice. Previous studies on these mice have demonstrated that the conformational change in P301L-tau is a necessary intermediate for further phosphorylation and aggregation (Shibuya et al., 2015). Thus, neurons in the mouse brain are fully capable of forming tau aggregates and tangles (Terwel et al., 2005). A reduction in tau has a protective effect in cultured neurons and animal models of AD (Roberson et al., 2007). In this manner, the inhibition or clearance of P301Ltau may be an effective therapeutic strategy for AD.

Se-Met has no influence on the expression of the TauP301L gene, and the reduction of tau by Se-Met can be achieved only by enhancing tau clearance. Autophagy is an essential process that initiates the cellular clearance of misfolded and aggregated proteins via autophagolysosomal fusion (Mizushima et al., 2010). Autophagic dysfunction has been directly linked to the pathogen- esis of AD (Boland et al., 2008). The reduction of autophagic activity that occurs in tauopathies results in the accumulation of abnormal and hyperphosphorylated tau (Inoue et al., 2012; Z. Zhang et al., 2014). Thus, modulation of the autophagic pathway is a promising approach for the clearance of tau and hyperphosphorylated tau. The protein kinase mTOR is important in the autophagy pathway and plays a key role in controlling cellular homeostasis via activation of p70S6 kinase and inhibition of autophagy (Klionsky and Emr, 2000). Overwhelming evidence has shown that pharmacological or genetic reduction in mTOR signaling increases the formation and activity of autophagy (Heras-Sandoval et al., 2014). Upregulated mTOR and p70S6K are associated with increased tau accumulation in AD brains, and inhibition of mTOR decreases the level of total tau in vitro and in vivo (Pei et al., 2006; Caccamo et al., 2010). mTOR also colocalizes with NFTs, mediates tau phosphorylation, and enhances tau aggregation (Tang et al., 2013). Consistent with these findings, we discovered that Se-Met significantly decreased mTOR and p70S6K expression both in vitro and in vivo. AMPK inhibits mTORC1 activity through activation of the tuberous sclerosis $1 /$ tuberous sclerosis 2 complex (Maiese, 2016). Thus, Se-Met initiates autophagy by up-regulating AMPK and inhibiting the activation of the mTOR pathway during the early stages of autophagy.

Enhanced lysosomal activity by Se-Met may also play a key role in the clearance of aggregated tau by effectively degrading LC3-II-positive autophagosomes. The p62 protein is selectively 
incorporated into autophagosomes via direct binding to LC3, and p62 is efficiently degraded by autophagy. Thus, p62 levels are inversely correlated with autophagic flux. The lysosomal proteolytic enzyme cathepsin D is the only aspartic-type protease ubiquitously expressed in all cells of the human body and abundantly expressed in the brain (Shacka and Roth, 2007). Generally, cathepsin D-mediated proteolysis is essential to neuronal cell homeostasis and involves the degradation of unfolded or oxidized protein aggregates delivered to lysosomes via autophagy. Neurons are particularly vulnerable to the loss of cathepsin D function (Vidoni et al., 2016). A number of studies have demonstrated that cathepsin D expression is decreased in $\mathrm{AD}$ (Urbanelli et al., 2008), and enhancing cathepsin D expression and activity restored the $\mathrm{A} \beta_{1-42}$-disturbed acid environment of lysosomes and promoted the fusion and clearance of autophagosomes with lysosomes (Zhang and Zhao, 2015). Se-Met decreased p62 expression and increased cathepsin D expression in primary cortical neurons and the hippocampus and cortex of $3 \mathrm{xTg}-\mathrm{AD}$ mice. Thus, Se-Met promoted autophagolysosomal fusion and improved autophagy flux, which enhanced the clearance of abnormal tau proteins. The N2a-sw cell line is a well known cellular model of AD. These cells were treated with bafilomycin Al in the absence or presence of $\mathrm{Se}-\mathrm{Met}$ to verify the effect of Se-Met on autophagic flux in $\mathrm{AD}$. In agreement with our in vivo results, Se-Met reversed the accumulation of LC-II and p62 and increased the presence of yellow and red puncta in mRFP-mWasabi-tandem fluorescent LC3transfected cells. These data show that Se-Met effectively restores bafilomycin-blocked autophagic flux.

Why does Se-Met influence the autophagy pathway in AD? Accumulating evidence suggests that oxidative stress plays a central role in the common pathophysiology of neurodegenerative diseases, including AD (G. H. Kim et al., 2015). The AD brain exhibits a significant increase in oxidative damage to lipids, protein, DNA, and RNA (Venkateshappa et al., 2012). Oxidative stress, which is present early in $\mathrm{AD}$ development, is influenced by autophagy. Thus, autophagy may be the link between oxidative stress and $\mathrm{AD}$ (Zheng et al., 2006). Oxidative stress and free radical damage play principal roles in cell death via the autophagic pathway and lysosome dysfunction (inhibition of lysosome enzyme function and lysosome membrane damage; Pivtoraiko et al., 2009). Oxidative stress induces lysosomal membrane permeabilization, improves lysosomal $\mathrm{pH}$, and inhibits cathepsin $\mathrm{D}$ activity (Hensley and Harris-White, 2015). Conversely, autophagy dysfunction can increase oxidative stress in $\mathrm{AD}$ (Zheng et al., 2006). Well characterized are the major biochemical and pharmacological properties of Se and Se-Met in contributing to oxidation resistance exerted by related selenoproteins and selenoenzymes. Therefore, there may be a close relationship between the effect of Se-Met on autophagy activation and its antioxidative activity. Additional studies are required to test this hypothesis.

In conclusion, our present study is the first to demonstrate that Se-Met reduces tau hyperphosphorylation via modulation of the Akt/GSK3 $\beta$ pathway, enhances autophagic flux and increases tau clearance through the autophagy-lysosome pathway, and rescues spatial learning and memory impairments in aged 3xTg-AD mice. These data shed light on a novel mechanism behind the therapeutic effect of Se-Met in AD.

\section{References}

Alonso A, Zaidi T, Novak M, Grundke-Iqbal I, Iqbal K (2001) Hyperphosphorylation induces self-assembly of tau into tangles of paired helical filaments/straight filaments. Proc Natl Acad Sci U S A 98:6923-6928. CrossRef Medline
Alzheimer's Association (2015) 2015 Alzheimer's disease facts and figures. Alzheimers Dement 11:332-384. CrossRef Medline

Avrahami L, Farfara D, Shaham-Kol M, Vassar R, Frenkel D, EldarFinkelman H (2013) Inhibition of glycogen synthase kinase-3 ameliorates beta-amyloid pathology and restores lysosomal acidification and mammalian target of rapamycin activity in the Alzheimer disease mouse model: in vivo and in vitro studies. J Biol Chem 288:1295-1306. CrossRef Medline

Balducci C, Forloni G (2014) In vivo application of beta amyloid oligomers: a simple tool to evaluate mechanisms of action and new therapeutic approaches. Curr Pharm Des 20:2491-2505. CrossRef Medline

Ballatore C, Lee VM, Trojanowski JQ (2007) Tau-mediated neurodegeneration in Alzheimer's disease and related disorders. Nat Rev Neurosci 8:663-672. CrossRef Medline

Berger Z, Roder H, Hanna A, Carlson A, Rangachari V, Yue M, Wszolek Z, Ashe K, Knight J, Dickson D, Andorfer C, Rosenberry TL, Lewis J, Hutton M, Janus C (2007) Accumulation of pathological tau species and memory loss in a conditional model of tauopathy. J Neurosci 27:3650-3662. CrossRef Medline

Boland B, Kumar A, Lee S, Platt FM, Wegiel J, Yu WH, Nixon RA (2008) Autophagy induction and autophagosome clearance in neurons: relationship to autophagic pathology in Alzheimer's disease. J Neurosci 28:69266937. CrossRef Medline

Bryan KJ, Lee H, Perry G, Smith MA, Casadesus G (2009) Transgenic mouse models of Alzheimer's disease: behavioral testing and considerations. In: Methods of behavior analysis in neuroscience, Ed 2 (Buccafusco JJ, ed), Chapter 1. Boca Raton, FL: CRC Press/Taylor \& Francis.

Caccamo A, Majumder S, Richardson A, Strong R, Oddo S (2010) Molecular interplay between mammalian target of rapamycin (mTOR), amyloid-beta, and Tau: effects on cognitive impairments. J Biol Chem 285:13107-13120. CrossRef Medline

Caceres A, Kosik KS (1990) Inhibition of neurite polarity by tau antisense oligonucleotides in primary cerebellar neurons. Nature 343:461-463. CrossRef Medline

Castro-Alvarez JF, Uribe-Arias A, Cardona-GómezGP (2015) Cyclindependent kinase 5 targeting prevents beta-amyloid aggregation involving glycogen synthase kinase 3beta and phosphatases. J Neurosci Res 93: 1258-1266. CrossRef Medline

Cuervo AM, Palmer A, Rivett AJ, Knecht E (1995) Degradation of proteasomes by lysosomes in rat liver. Eur J Biochem 227:792-800. CrossRef Medline

Ding H, Matthews TA, Johnson GV (2006) Site-specific phosphorylation and caspase cleavage differentially impact tau-microtubule interactions and tau aggregation. J Biol Chem 281:19107-19114. CrossRef Medline

Dolan PJ, Johnson GV (2010) The role of tau kinases in Alzheimer's disease. Curr Opin Drug Discov Dev 13:595-603. Medline

Eckert A, Schulz KL, Rhein V, GötzJ (2010) Convergence of amyloid-beta and tau pathologies on mitochondria in vivo. Mol Neurobiol 41:107-114. CrossRef Medline

Gao S, Jin Y, Hall KS, Liang C, Unverzagt FW, Ji R, Murrell JR, Cao J, Shen J, Ma F, Matesan J, Ying B, Cheng Y, Bian J, Li P, Hendrie HC (2007) Selenium level and cognitive function in rural elderly Chinese. Am J Epidemiol 165:955-965. CrossRef Medline

Gao S, Jin Y, Unverzagt FW, Liang C, Hall KS, Cao J, Ma F, Murrell JR, Cheng Y, Li P, Bian J, Hendrie HC (2012) Selenium level and depressive symptoms in a rural elderly Chinese cohort. BMC Psychiatry 12:72. CrossRef Medline

Gendron TF, Petrucelli L (2009) The role of tau in neurodegeneration. Mol Neurodegener 4:13. CrossRef Medline

Gwon AR, Park JS, Park JH, Baik SH, Jeong HY, Hyun DH, Park KW, Jo DG (2010) Selenium attenuates A beta production and A beta-induced neuronal death. Neurosci Lett 469:391-395. CrossRef Medline

Hanger DP, Anderton BH, Noble W (2009) Tau phosphorylation: the therapeutic challenge for neurodegenerative disease. Trends Mol Med 15: 112-119. CrossRef Medline

Harada A, Oguchi K, Okabe S, Kuno J, Terada S, Ohshima T, Sato-Yoshitake R, Takei Y, Noda T, Hirokawa N (1994) Altered microtubule organization in small-calibre axons of mice lacking tau protein. Nature 369:488491. CrossRef Medline

Hensley K, Harris-White ME (2015) Redox regulation of autophagy in healthy brain and neurodegeneration. Neurobiol Dis 84:50-59. CrossRef Medline 
Heras-Sandoval D, Pérez-Rojas JM, Hernández-DamiánJ, Pedraza-Chaverri J (2014) The role of PI3K/AKT/mTOR pathway in the modulation of autophagy and the clearance of protein aggregates in neurodegeneration. Cell Signal 26:2694-2701. CrossRef Medline

Hernandez F, Lucas JJ, Avila J (2013) GSK3 and tau: two convergence points in Alzheimer's disease. J Alzheimers Dis 33 [Suppl 1]:S141-S144.

Hu ZH, Tian Q, Wang JZ (2006) [Role of serine/threonine protein phosphatase in tau phosphorylation]. Sheng Li Ke Xue Jin Zhan 37:173-174. Medline

Hunsberger HC, Rudy CC, Weitzner DS, Zhang C, Tosto DE, Knowlan K, Xu Y, Reed MN (2014) Effect size of memory deficits in mice with adultonset P301L tau expression. Behav Brain Res 272:181-195. CrossRef Medline

Hurtado DE, Molina-Porcel L, Iba M, Aboagye AK, Paul SM, Trojanowski JQ, Lee VM (2010) A $\{$ beta $\}$ accelerates the spatiotemporal progression of tau pathology and augments tau amyloidosis in an Alzheimer mouse model. Am J Pathol 177:1977-1988. CrossRef Medline

Inoue K, Rispoli J, Kaphzan H, Klann E, Chen EI, Kim J, Komatsu M, Abeliovich A (2012) Macroautophagy deficiency mediates age-dependent neurodegeneration through a phospho-tau pathway. Mol Neurodegener 7:48. CrossRef Medline

Jiang T, Yu JT, Zhu XC, Zhang QQ, Tan MS, Cao L, Wang HF, Shi JQ, Gao L, Qin H, Zhang YD, Tan L (2015) Ischemic preconditioning provides neuroprotection by induction of AMP-activated protein kinasedependent autophagy in a rat model of ischemic stroke. Mol Neurobiol 51:220-229. CrossRef Medline

Kim GH, Kim JE, Rhie SJ, Yoon S (2015) The role of oxidative stress in neurodegenerative diseases. Exp Neurobiol 24:325-340. CrossRef Medline

Kim Y, Park H, Nah J, Moon S, Lee W, Hong SH, Kam TI, Jung YK (2015) Essential role of POLDIP2 in Tau aggregation and neurotoxicity via autophagy/proteasome inhibition. Biochem Biophys Res Commun 462: 112-118. CrossRef Medline

Klionsky DJ, Emr SD (2000) Autophagy as a regulated pathway of cellular degradation. Science 290:1717-1721. CrossRef Medline

Komatsu M, Waguri S, Chiba T, Murata S, Iwata J, Tanida I, Ueno T, Koike M, Uchiyama Y, Kominami E, Tanaka K (2006) Loss of autophagy in the central nervous system causes neurodegeneration in mice. Nature 441: 880-884. CrossRef Medline

Komatsu M, Waguri S, Koike M, Sou YS, Ueno T, Hara T, Mizushima N, Iwata J, Ezaki J, Murata S, Hamazaki J, Nishito Y, Iemura S, Natsume T, Yanagawa T, Uwayama J, Warabi E, Yoshida H, Ishii T, Kobayashi A, et al. (2007) Homeostatic levels of p62 control cytoplasmic inclusion body formation in autophagy-deficient mice. Cell 131:1149-1163. CrossRef Medline

Kopeikina KJ, Hyman BT, Spires-Jones TL (2012) Soluble forms of tau are toxic in Alzheimer's disease. Transl Neurosci 3:223-233. Medline

Levine B, Klionsky DJ (2004) Development by self-digestion: molecular mechanisms and biological functions of autophagy. Dev Cell 6:463-477. CrossRef Medline

Liu F, Li B, Tung EJ, Grundke-Iqbal I, Iqbal K, Gong CX (2007) Site-specific effects of tau phosphorylation on its microtubule assembly activity and self-aggregation. Eur J Neurosci 26:3429-3436. CrossRef Medline

Maiese K (2016) Targeting molecules to medicine with mTOR, autophagy, and neurodegenerative disorders. Br J Clin Pharmacol 82:1245-1266. CrossRef Medline

Maphis N, Xu G, Kokiko-Cochran ON, Cardona AE, Ransohoff RM, Lamb BT, Bhaskar K (2015) Loss of tau rescues inflammation-mediated neurodegeneration. Front Neurosci 9:196. Medline

Marzella L, Ahlberg J, Glaumann H (1982) Isolation of autophagic vacuoles from rat liver: morphological and biochemical characterization. J Cell Biol 93:144-154. CrossRef Medline

Mendelev N, Mehta SL, Idris H, Kumari S, Li PA (2012) Selenite stimulates mitochondrial biogenesis signaling and enhances mitochondrial functional performance in murine hippocampal neuronal cells. PLoS One 7:e47910. CrossRef Medline

Mizushima N, Levine B, Cuervo AM, Klionsky DJ (2008) Autophagy fights disease through cellular self-digestion. Nature 451:1069-1075. CrossRef Medline

Mizushima N, Yoshimori T, Levine B (2010) Methods in mammalian autophagy research. Cell 140:313-326. CrossRef Medline

Oddo S, Caccamo A, Shepherd JD, Murphy MP, Golde TE, Kayed R, Mether- ate R, Mattson MP, Akbari Y, LaFerla FM (2003a) Triple-transgenic model of Alzheimer's disease with plaques and tangles: intracellular Abeta and synaptic dysfunction. Neuron 39:409-421. CrossRef Medline

Oddo S, Caccamo A, Kitazawa M, Tseng BP, LaFerla FM (2003b) Amyloid deposition precedes tangle formation in a triple transgenic model of Alzheimer's disease. Neurobiol Aging 24:1063-1070. CrossRef Medline

Orr ME, Salinas A, Buffenstein R, Oddo S (2014) Mammalian target of rapamycin hyperactivity mediates the detrimental effects of a high sucrose diet on Alzheimer's disease pathology. Neurobiol Aging 35:1233-1242. CrossRef Medline

Pei JJ, An WL, Zhou XW, Nishimura T, Norberg J, Benedikz E, Götz J, Winblad B (2006) P70 S6 kinase mediates tau phosphorylation and synthesis. FEBS Lett 580:107-114. CrossRef Medline

Pivtoraiko VN, Stone SL, Roth KA, Shacka JJ (2009) Oxidative stress and autophagy in the regulation of lysosome-dependent neuron death. Antioxid Redox Signal 11:481-496. CrossRef Medline

Roberson ED, Scearce-Levie K, Palop JJ, Yan F, Cheng IH, Wu T, Gerstein H, Yu GQ, Mucke L (2007) Reducing endogenous tau ameliorates amyloid beta-induced deficits in an Alzheimer's disease mouse model. Science 316:750-754. CrossRef Medline

Santacruz K, Lewis J, Spires T, Paulson J, Kotilinek L, Ingelsson M, Guimaraes A, DeTure M, Ramsden M, McGowan E, Forster C, Yue M, Orne J, Janus C, Mariash A, Kuskowski M, Hyman B, Hutton M, Ashe KH (2005) Tau suppression in a neurodegenerative mouse model improves memory function. Science 309:476-481. CrossRef Medline

Schmelzle T, Hall MN (2000) TOR, a central controller of cell growth. Cell 103:253-262. CrossRef Medline

Shacka JJ, Roth KA (2007) Cathepsin D deficiency and NCL/Batten disease: there's more to death than apoptosis. Autophagy 3:474-476. CrossRef Medline

Shibuya Y, Chang CC, Huang LH, Bryleva EY, Chang TY (2014) Inhibiting ACAT1/SOAT1 in microglia stimulates autophagy-mediated lysosomal proteolysis and increases Abeta1-42 clearance. J Neurosci 34:1448414501. CrossRef Medline

Shibuya Y, Niu Z, Bryleva EY, Harris BT, Murphy SR, Kheirollah A, Bowen ZD, Chang CC, Chang TY (2015) Acyl-coenzyme A:cholesterol acyltransferase 1 blockage enhances autophagy in the neurons of triple transgenic Alzheimer's disease mouse and reduces human P301L-tau content at the presymptomatic stage. Neurobiol Aging 36:2248-2259. CrossRef Medline

Siman R, Cocca R, Dong Y (2015) The mTOR inhibitor rapamycin mitigates perforant pathway neurodegeneration and synapse loss in a mouse model of early-stage Alzheimer-type tauopathy. PLoS One 10:e0142340. CrossRef Medline

Song G, Zhang Z, Wen L, Chen C, Shi Q, Zhang Y, Ni J, Liu Q (2014) Selenomethionine ameliorates cognitive decline, reduces tau hyperphosphorylation, and reverses synaptic deficit in the triple transgenic mouse model of Alzheimer's disease. J Alzheimers Dis 41:85-99. Medline

Sontag JM, Sontag E (2014) Protein phosphatase 2A dysfunction in Alzheimer's disease. Front Mol Neurosci 7:16. Medline

Su J, Zhang T, Wang K, Zhu T, Li X (2014) Autophagy activation contributes to the neuroprotection of remote ischemic perconditioning against focal cerebral ischemia in rats. Neurochem Res 39:2068-2077. CrossRef Medline

Sui HJ, Zhang LL, Liu Z, Jin Y (2015) Atorvastatin prevents Abeta oligomerinduced neurotoxicity in cultured rat hippocampal neurons by inhibiting Tau cleavage. Acta Pharmacol Sin 36:553-564. CrossRef Medline

Tang Z, Bereczki E, Zhang H, Wang S, Li C, Ji X, Branca RM, LehtiöJ, Guan Z, Filipcik P, Xu S, Winblad B, Pei JJ (2013) Mammalian target of rapamycin (mTor) mediates tau protein dyshomeostasis: implication for Alzheimer disease. J Biol Chem 288:15556-15570. CrossRef Medline

Terwel D, Lasrado R, Snauwaert J, Vandeweert E, Van Haesendonck C, Borghgraef P, Van Leuven F (2005) Changed conformation of mutant Tau-P301L underlies the moribund tauopathy, absent in progressive, nonlethal axonopathy of Tau-4R/2N transgenic mice. J Biol Chem 280 : 3963-3973. CrossRef Medline

Urbanelli L, Emiliani C, Massini C, Persichetti E, Orlacchio A, Pelicci G, Sorbi S, Hasilik A, Bernardi G, Orlacchio A (2008) Cathepsin D expression is decreased in Alzheimer's disease fibroblasts. Neurobiol Aging 29:12-22. CrossRef Medline

van Eersel J, Ke YD, Liu X, Delerue F, Kril JJ, Götz J, Ittner LM (2010) Sodium selenate mitigates tau pathology, neurodegeneration, and func- 
tional deficits in Alzheimer's disease models. Proc Natl Acad Sci U S A 107:13888-13893. CrossRef Medline

Venkateshappa C, Harish G, Mahadevan A, Srinivas Bharath MM, Shankar SK (2012) Elevated oxidative stress and decreased antioxidant function in the human hippocampus and frontal cortex with increasing age: implications for neurodegeneration in Alzheimer's disease. Neurochem Res 37:1601-1614. CrossRef Medline

Vidoni C, Follo C, Savino M, Melone MA, Isidoro C (2016) The role of cathepsin D in the pathogenesis of human neurodegenerative disorders. Med Res Rev 36:845-870. CrossRef Medline

Vossel KA, Zhang K, Brodbeck J, Daub AC, Sharma P, Finkbeiner S, Cui B, Mucke L (2010) Tau reduction prevents Abeta-induced defects in axonal transport. Science 330:198. CrossRef Medline

Vossel KA, Xu JC, Fomenko V, Miyamoto T, Suberbielle E, Knox JA, Ho K, Kim DH, Yu GQ, Mucke L (2015) Tau reduction prevents Abetainduced axonal transport deficits by blocking activation of GSK3beta. J Cell Biol 209:419-433. CrossRef Medline

Wang JZ, Gao X, Wang ZH (2014) The physiology and pathology of microtubule-associated protein tau. Essays Biochem 56:111-123. CrossRef Medline

Wang Y, Yang R, Gu J, Yin X, Jin N, Xie S, Wang Y, Chang H, Qian W, Shi J, Iqbal K, Gong CX, Cheng C, Liu F (2015) Cross talk between PI3KAKT-GSK-3beta and PP2A pathways determines tau hyperphosphorylation. Neurobiol Aging 36:188-200. CrossRef Medline

Yang DS, Stavrides P, Saito M, Kumar A, Rodriguez-Navarro JA, Pawlik M, Huo C, Walkley SU, Saito M, Cuervo AM, Nixon RA (2014) Defective macroautophagic turnover of brain lipids in the TgCRND8 Alzheimer mouse model: prevention by correcting lysosomal proteolytic deficits. Brain 137:3300-3318. CrossRef Medline

Yu CJ, Liu W, Chen HY, Wang L, Zhang ZR (2014) BACE1 RNA interference improves spatial memory and attenuates Abeta burden in a streptozotocin-induced tau hyperphosphorylated rat model. Cell Biochem Funct 32:590-596. CrossRef Medline

Zare-Shahabadi A, Masliah E, Johnson GV, Rezaei N (2015) Autophagy in Alzheimer's disease. Rev Neurosci 26:385-395. Medline

Zhang Y, Ma RH, Li XC, Zhang JY, Shi HR, Wei W, Luo DJ, Wang Q, Wang JZ, Liu GP (2014) Silencing [Formula: see text] rescues tau pathologies and memory deficits through rescuing PP2A and inhibiting GSK-3beta signaling in human tau transgenic mice. Front Aging Neurosci 6:123. Medline

Zhang YD, Zhao JJ (2015) TFEB participates in the Abeta-induced pathogenesis of Alzheimer's disease by regulating the autophagy-lysosome pathway. DNA Cell Biol 34:661-668. CrossRef Medline

Zhang Z, Song M, Liu X, Kang SS, Kwon IS, Duong DM, Seyfried NT, Hu WT, Liu Z, Wang JZ, Cheng L, Sun YE, Yu SP, Levey AI, Ye K (2014) Cleavage of tau by asparagine endopeptidase mediates the neurofibrillary pathology in Alzheimer's disease. Nat Med 20:1254-1262. CrossRef Medline

Zheng L, Marcusson J, Terman A (2006) Oxidative stress and Alzheimer disease: the autophagy connection? Autophagy 2:143-145. CrossRef Medline

Zhou C, Zhong W, Zhou J, Sheng F, Fang Z, Wei Y, Chen Y, Deng X, Xia B, Lin J (2012) Monitoring autophagic flux by an improved tandem fluorescent-tagged LC3 (mTagRFP-mWasabi-LC3) reveals that highdose rapamycin impairs autophagic flux in cancer cells. Autophagy 8:1215-1226. CrossRef Medline 